


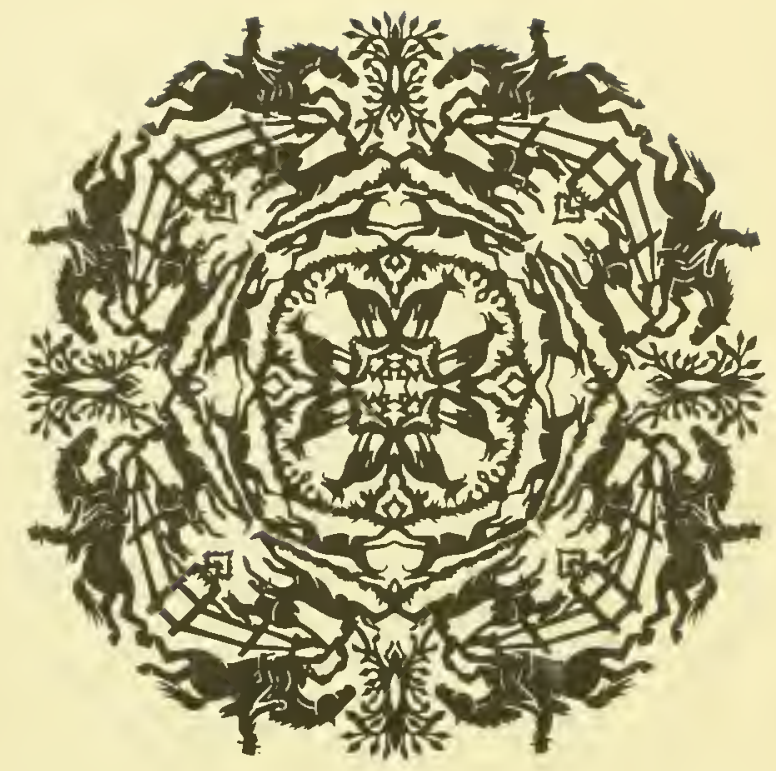

JOHN A.SEAVERNS 
Lo ins shaws.

fim. 9.7. gokason.

2P.P. Tohesa.

Wita ykeir Beas Wirks.

Xnas $/ 9 / 6$. 


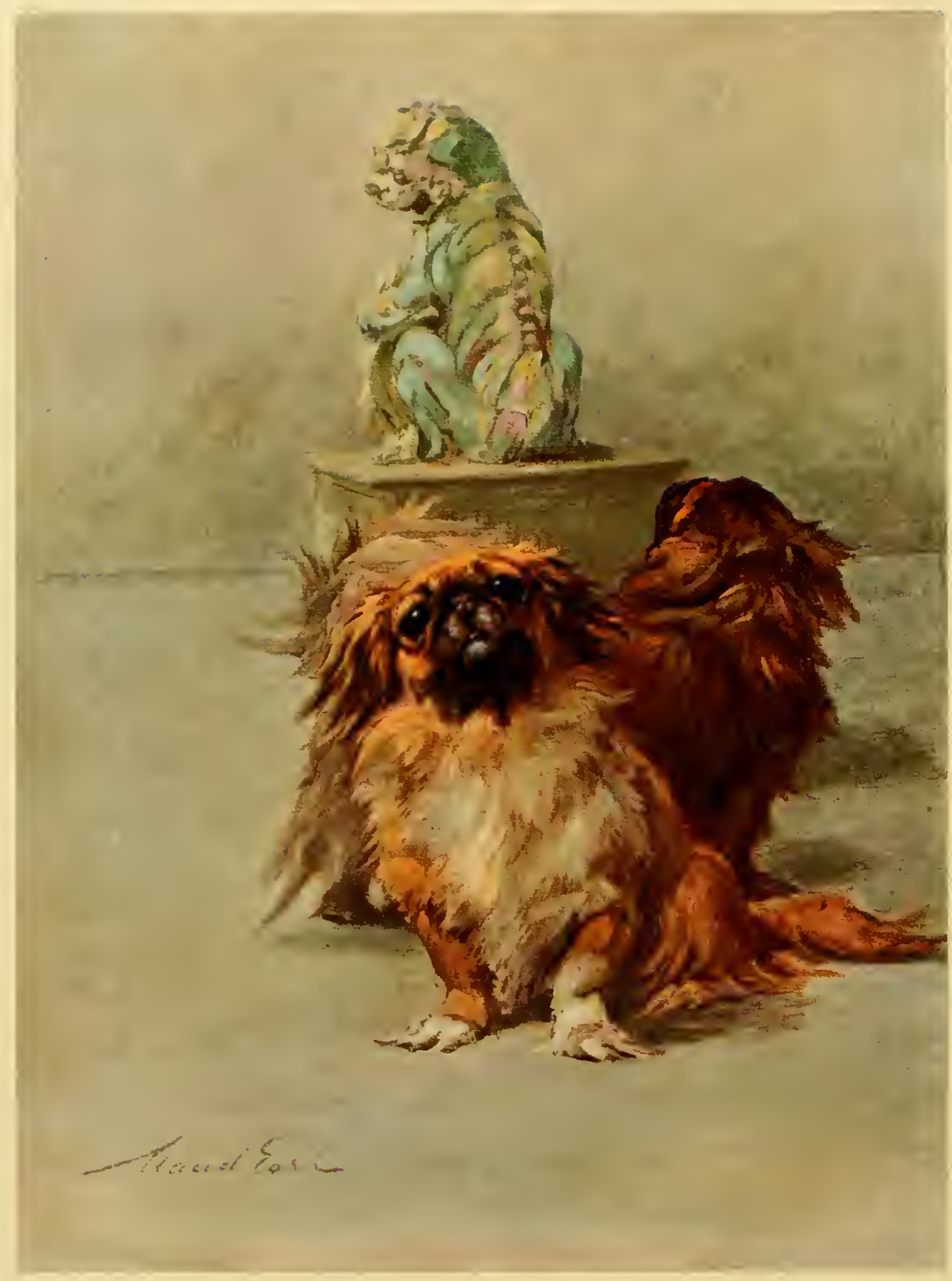




\section{The Power of the Dog}

Twenty Plates in Colour

by

MAUD EARL

DESCRIBED BY A. CROXTON SMITH

HODDER AND STOUGHTON

LONDON NEW YORK TORONTO 
ILLUSTRATIONS

I.

THE FOXHOUND

Foxhounds. Owned by Sir Hugo Fitzherbert, Bart.

II.

THE BLOODHOUND

Bloodhound "Cui Bomo." Owned by Mrs. Barmett Burn

III.

THE POINTER

Pointer "Flax:" Oroned by William Arkwright, Esq.

IV.

THE GREYHOUND

Greyhounds "Spirituelle," oroned by Mr. R. N. Stollery". "Rupert of Debate," orened by Mr. E. V. Raynes

V.

THE PYRENEAN MOUNTAIN DOG

Pyrenean Mountain Dog "Milanollo Néthou." Owned by Lady Sybil Grant 
VI.

THE WELSH TERRIER

Welsh Terriers "Ch. Longmynd Pypyr" and "Longmynd Taffitus." Owned by Mrs. H. D. Greene

VII.

THE SCOTTISH TERRIER

Scottish Terrier "Scotty." Owned by The Hon. Mrs. Charles Tufton

VIII.

THE SEALYHAM TERRIER

Sealyham Terrier "Peer Gynt." Owned by Mr. Harry Jones

IX.

THE FOX TERRIER

Fox Terrier Puppy

$\mathrm{X}$.

THE WEST HIGHLAND WHITE TERRIER

West Highland White Terriers "Tissie" and "Tamner." Owoned by Mrs. Lionel Faudel Phillips

XI.

THE MINIATURE BULLDOG

Miniature Bulldogs "Champion Cheret Punch" and "Cheret Daisy." Owned by Lady Kathleen Pilkington 
XII.

THE BULL TERRIER

Bull Terrier "Buller." Ozoned by Mr. Dawusan

XIII.

THE CHOW CHOW

Chow "Champion Papoose." Owned by Mrs. Lionel Faudel Phillips

XIV.

THE PEKINGESE

Pekingese "Nan Tye of Neronham" and "Ch. Mai-Mai of Neronham." Ozoned by Mrs. William Herbert

$X V$.

THE MINIATURE POMERANIAN

Miniature Pomeranian "Gatacre Betty." Owned by Mrs. Hall Walker.

XVI.

THE ENGLISH SPRINGER

English Springer "Tissington Flush." Owned by Sir Hugo Fitzherbert, Bart.

XVII.

THE BOSTON TERRIER

Boston Terrier "Yeffries Junior." Owned by Miss Clandia Lasell 
XYIII.

THE GRIFFON BRUXELLOIS

Griffons Bruxellois "Park Place Presto," "Park Place Pinkie," "Champion Park Place Partisan," and "Esperance." Owned by Miss Hall

XIX.

THE MINIATURE POODLE

Miniature Poodle "Whippendell Pirouette." Ozoned by" Miss Brunker

$\mathrm{XX}$.

A PEKINGESE PUPPY

Pekingese Puppy "Ln Chu of Newnham." Oioned by Mrs. Willicam Herbert 
"Uncouple in the ralley; let them go;

Ant murk the musical confusion

Of hounts and echo in conjunction."

Shakespeare- 1 Midsmmer Night's Direm.

FOXHOUNDS

Orened by Sir Hugno Fitaherbert, Bart. 


\section{THE FOXHOUND}

On the straightest of tegs, and the roundest of feet, Writh ribs like a frigate his timbers to meet, With a fashion and fling and a form so complete, That to see him chance ore' the flugs is a treat.

Whyte Melville.

S fine a picture of the ideal foxhound as one could wish to
$\mathrm{A}$ put in print is conveyed by these words of Whyte Melville, although the further reminder is necessary that fashion and form without nose are in vain. The handsomest hound in the world is a sorry impostor if he will not own to the line when scent is light. Fox hunting is the essence of sport. There is nothing that can equal it, looking at it all round. Big game shooting has its excitements and hair breadth adventures, pig sticking in India, and hunting the wild boar in France are recreations fit for men, but when we come to consider the innumerable qualifications necessary to make a good follower of hounds the palm must be assigned to fox hunting. In the words of the immortal Mr. Jorrocks: "Unting is the sport of kings, the image of war without its guilt, and only five-andtwenty per cent. of its danger! In that word ' 'unting,' wot a 
ramification of knowledge is compressed! The choice of an 'oss--the treatment of him when got---the boots, the breeches, the saddle, the bridle, the 'ound, the 'untsman, the feeder, the Fox! Oh, how that beautiful word Fox gladdens my 'eart, and warms the declinin' embers of my age. 'The 'oss and the 'ound were made for each other, and natur' threw in the Fox as a connectin' link between the two." "

No other sport unites all classes to such an extent or brings men and women together in such wholesome rivalry. Courage, skill, judgment and self-restraint are only some of the qualities brought into play.

Boys to the hunting field. Though 'tis November, The wind's in the south; but a word ere we start:

However excited, you'll please to remember

That hunting's a science and riding an art.

The fox takes precedence of all from the covert,

The hunter's an animal purposely bred,

After the pack to he ridden, not over,

Foxhounds are not reared to be knock'd on the head.

Pastime for princes, prime sport of our nation,-

Strength to their sinew, a bloom on their cheek;

Health to the old, to the young recreation,

All for enjoyment the hunting field seek.

No excuse is needed for quoting these words of Mr. Egerton Warburton, from a poem said by the late Duke of Westminster to 
emboly the whole code of honour and practice which it becomes a gentleman to obey in the hunting field.

That it is a costly amusement, goes without saying, especiaily if our Nimrod elects to hunt in one of the fashionable countries where the pace necessitates a large stud of horses, but there are still packs in existence which make more modest demands upon the purse, and perhaps show better hound work, even if fewer foxes are killed. The old trencher-fed packs, which provided sport at a minimum of expense, are, alas, disappearing, very few now being found in any part of the country. 'They had the advantage of interesting the farmers and small local men to an extent that is out of the question with other packs. Presumably the objections to the system were stronger than the advantages, otherwise it would not be allowed to fall into desuetude. On the one side, it may be said that hounds cared for by a number of people are less liable to suffer from diseases which are inevitable when many are kennelled together. On the other, hounds so reared cannot possibly be kept in the sound condition desirable for a hard day's work, and there was usually a lack of discipline in the field which was not always conducive to success.

The influence of fox hunting upon the social and economic side of rural life is one that should not be overlooked. It means that during the winter months thousands of wealthy men and 
women are content to reside in the country who would otherwise hibernate in towns, and the money expended upon the keep of horses runs into enormous sums. Farmers may grumble at times at the damage done, and contend that the compensation paid them is inadequate, but they get their own back with interest in other directions. What the future has in store for the sport is another matter. Fields may grow so unwieldly as to be a menace to agriculture; Masters may find a pack too costly a luxury with a growing taxation and increasing outlay in other directions. In fact, many considerations might be urged which may, in years to come, be sufficiently potent to overcome the glamour and enthusiasm which now surround the pursuit. Who can say?

As for the hound himself, what can be said that has not already been well said by hundreds of writers? He is the very perfection of dog flesh, beautiful to look upon in his symmetry and strength. For many generations men have brought skill and experience to bear upon the improvement of nature, for nature in herself is not necessarily perfect. She supplies us with the raw material, which we mould and fashion to suit our intent. Some think that certain points are being pushed to extremes, such, for instance, as the craze for straight fronts. True, in a hound we want great bone.carried well down to the feet, but it is not an uncommon thing to see the forelegs knuckling over in a manner which is dangerously near unsoundness. 



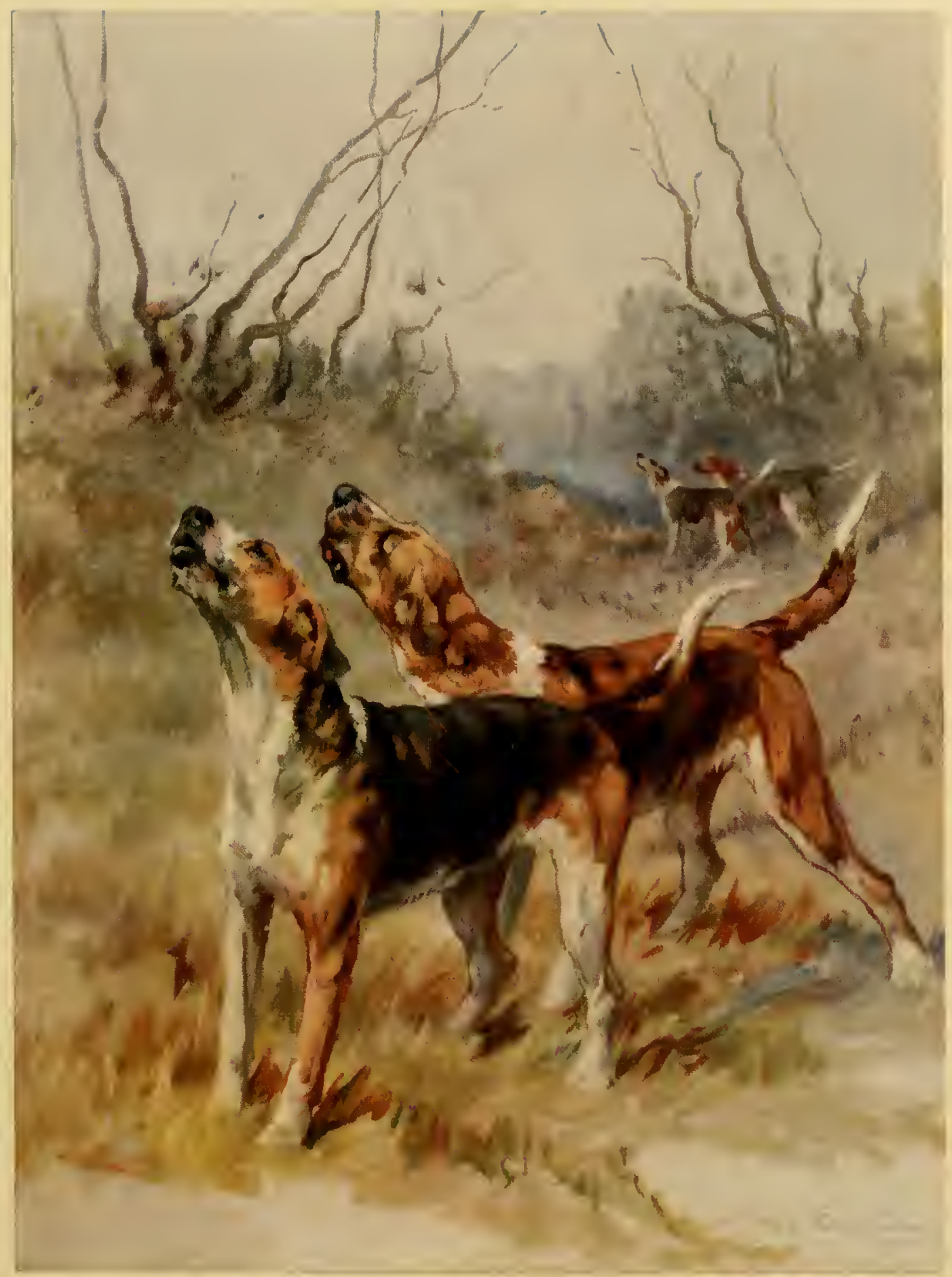



"I have se'" all things pass and all men go, under. the shadow of the drifting leaf."

Fiona Macleod.

BLOODHOUND

"Cui Bono"

Orivid by Mrs. Barmett Burn 


\section{THE BLOODHOUND \\ And hark! and hark! the deep-msuthed bark \\ Come's nigher still, and nigher; \\ Bursts on the path a dark bloodhound, \\ His tawny mus:ele tracked the ground, \\ And his red eye shot fire.}

ScotT.

F all the Saints in the calendar the sportsman has most reason
to remember the goodly Abbot of the Ardennes, St. Hubert, after whom were named two strains of mighty hounds, the black and the white. Devotion to the memory of the founder of the Abbey induced successive Abbots to cherish the hounds, from which are descended the fine varieties found in France and Great Britain unto this day. William the Conqueror had the honour of introducing the bloodhound into this country, where he has remained ever since under several styles---lyme hound, sleuth hound, etc. Right down the pages of history we find him popping up, sometimes with sinister import, as when he nearly succeeded in bringing Robert Bruce into the hands of his pursuers. The fugitive escaped by the familiar device of wading along a burn: 
Rycht to the burn thai passet ware,

Bot the sleuth-hound made stinting thar.

And waueryt lang type ta and fra,

That he na certain gate couth ga;

Till at the last that John of Lorn

Perseuvit the hund the sleuth had lorne.

So hard a-dying are old prejudices that unto this day this noble hound, gentlest of his kind, is regarded with a kind of awe. Time after time have I known a lady pet and fondle one, with the the remark, "What a beatutiful creature. What kind of dog is he?" and when she has heard the dread name she has recoiled in fear. It is useless to tell her that one rarely sees a bad tempered bloodhound, that they are the kindliest mannered gentlemen that ever walked. She thinks of "Uncle Tom's Cabin," and associates the name in some way with a thirst for blood. That is sufficient.

In modern times the uses of the bloodhound, when properly applied, are wholly beneficent. Those marvellous scenting faculties of his, which astonish all who see them at their fullest development, may aid in bringing a criminal to justice or in discovering the whereabouts of a wanderer lost in the wilds. The hound little recks of the task to which he is being put. His not to reason why. Ask him to unravel the intricacies of an invisible track left by the body scent of a person who may have passed many hours earlier, and, if he be well triined, down goes his nose, and he will follow yard by yard until the missing one is found. This is no 
imaginative picture conjured up by excessive devotion. That the thing can be done has been demonstrated times without number, and if there are failures, as failures there must be, we should not blame the hound so much as those who have had his education in hand. The instinct is present in practically all, although, naturally, it is more fully developed in some than others. All that is needed is for man to draw it out by his knowledge of hound work, aided by patience. It would be just about as stupid to expect a beginner to work a line eighteen hours cold as it would to chide a year-old infant for tumbling in his earliest essays to stand alone. Line upon line, precept upon precept. First a short distance, hot upon the footsteps of the runner; then further afield and with a longer interval elapsing, until you may despatch the quarry over night and ask the hound in the morning to show you where he has been. As a further refinement in the educative processes the line may be crossed here and there by strangers, with the intent of teaching the tracker to discriminate between the true and the false. If he is worth his keep his sensitive olfactory nerves will have stored up impressions of the original scent which never can be effaced by any attempts to foil the track.

One of the great advantages of keeping a bloodhound is that the delicacies of hound work may be observed without the infliction of cruelty upon another animal, and at a small expense. At the same time one has the pleasure of feeling that in his possession is 
an agent that may on occasion aid the police in tracing the whereabouts of a criminal, or in restoring a lost child to his home. Country gentlemen especially, with large estates, might find a couple of bloodhounds morc potent protection against the depredations of poachers than several keepers. I have heard of an estate in Ireland being entirely freed from this nuisance at very little cost. For companionship a bloodhound is more suited to the country than a town. Unless to the manner born, he is not as handy in avoiding traffic as dogs which are in the habit of relying upon their eyes and ears. His nose instinctively is near the ground, and unless your attention is on him he might easily blunder under motor or cart. If taken in hand when young he is as amenable to discipline as any other breed, and, owing to his affectionate disposition, he will become deeply attached to master or mistress. 



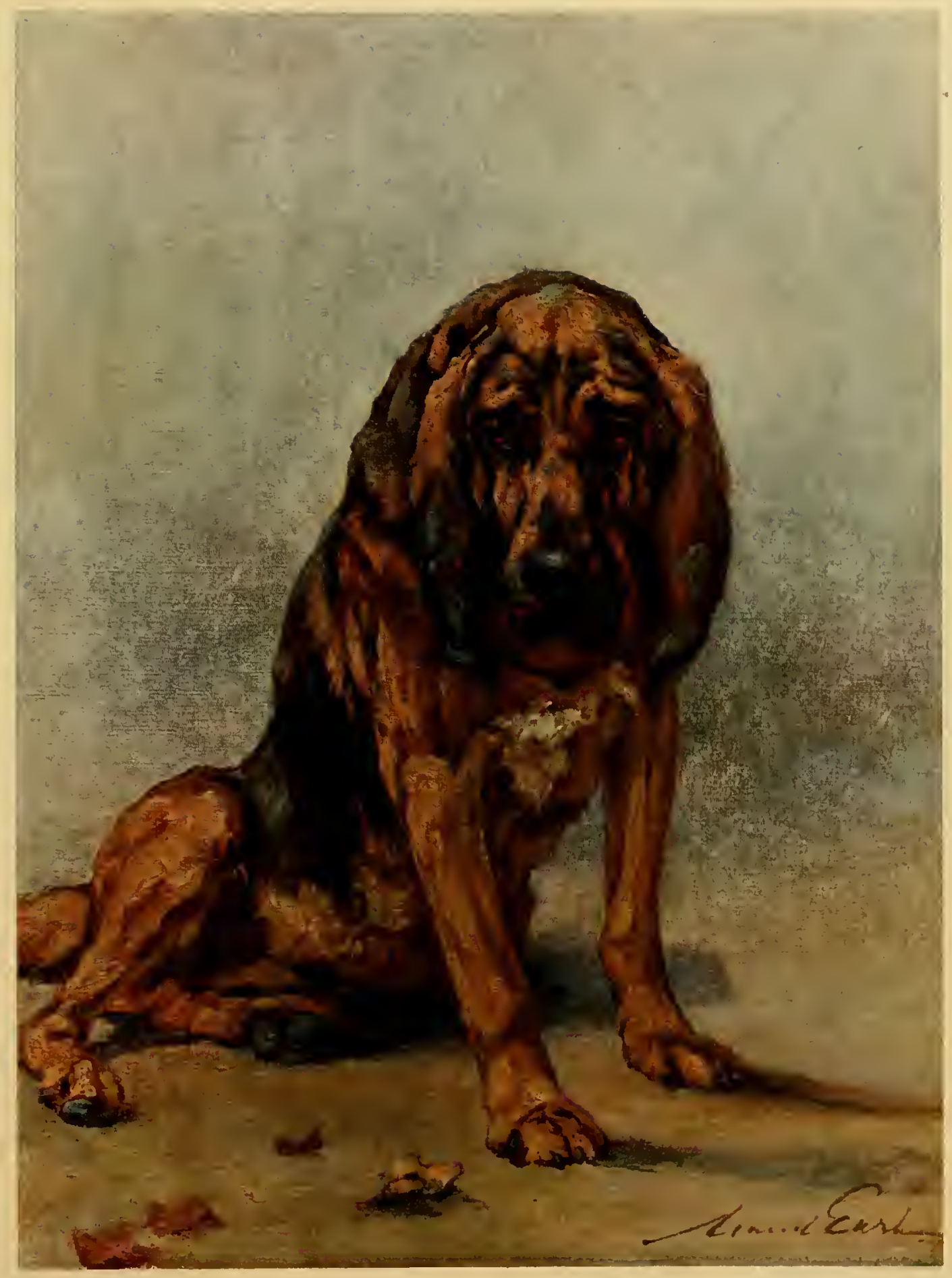



"His nostril wide into the murky air Sagacious of his quarry from so far."

Milton-Paradise Lost.

\section{POINTER}

"Flax"

Owned by William Arkwight, Esq. 


\section{THE POINTER}

Stiff by the tainted gale with open nose, Ontstretch'd and finely sensible, draws full, Fearfiul, and cautious, on the latent prey; As in the sun the circling covey bask

Their varied plumes, and, watchful every way, Through the rough stubble turn the secret eye.

THOMSON.

HE respective virtues of the Pointer and Setter have been

1 discussed without stint for many years, the advocates of each retaining their opinions uninfluenced by the arguments on the other side. It may not be known that no less a person than Sir Walter Scott once had a mild hand in the game. In "St. Ronan's Well," if you turn to the account of the dinner party which led to much ill-humour, you will find these remarks: "The company were talking of shooting, the most animating topic of conversation among Scottish country gentlemen of the younger class, and Tyrrel had mentioned something of a favourite setier, an uncommonly handsome dog, from which he had been for some time separated, but which he expected would rejoin him in the course of next 
week. 'A setter,' retorted Sir Bingo with a sneer; 'a pointer, I suppose you mean?" 'No, sir,' said Tyrrel; 'I am perfectly aware of the difference betwixt a setter and a pointer, and I know the old-fashioned setter is become unfashionable among modern sportsmen. But I love my dog as a companion, as well as for his merits in the field; and a setter is more sagacious, more attached, and fitter for his place on the hearth-rug, than a pointer---not,' he added, 'from any deficiency of intellects on the pointer's part, but he is generally so abused while in the management of brutal breakers and grooms that he loses all excepting his professional accomplishments, of finding and standing steady to game."

Sir Bingo could not understand why one should wish for anything more. He never before heard that a setter was fit to follow any man's heels but a poacher's. Tyrrel's point was that " many people have been of opinion, that both dogs and men may follow sport indifferently well, though they do happen, at the same time, to be fit for mixing in friendly intercourse in society." A sentiment which we cordially approve. Whether the shooting man should select a Pointer or Setter to aid him in the field or on the moor resolves itself very largely into a question of individual taste. Either, when well broken, is capable of carrying out his highly specialized duties with great skill, and no prettier sight can be imagined than a brace of these clever animals quartering the ground and coming to a statuesque point when the game is winded. Of 
course, in externals the two breeds present many striking differences. Some admire the beautiful coat and gentle expression of the Setter, while others there are who declare that:

\section{Loveliness}

Needs not the foreign aid of ornament, But is, when unadorn'd, adorn'd the most.

In other words, form appeals more to them than coat. They dwell upon the handsome outline of the Pointer, his symmetrical, powverfully knit body, his straight legs and muscular quarters. The modern dog is not without his critics, however, who contend that a foxhound cross has been used in modern times as well as many years ago, and that the hound qualities introduced are detrimental rather than otherwise. It is urged that the duties demanded of the Pointer are even more exacting than those of the foxhound, as regards stamina, and that if the old dogs could perform them creditably there was no occasion to resort to outside blood, which developed a headstrong disposition that renders breaking more difficult, and tends to unsteadiness. In justice to the other disputants, it should be explained that they deny the alien cross, and contend that, as the foxhound is a perfect piece of mechanism, Pointer breeders are justified in attempting to work up to such a worthy model. Although one does not ask for a potterer it is questionable if great pace in a gundog is either necessary or desirable, for the fast animal is liable to pass birds that a slower one would find. 
After all, the truest test of excellence is finding birds for the guns, a feat in which the flashy worker is not always proficient.

In the innumerable letters which have appeared upon the subject I have never seen reference to the remarks of General Hutchinson. Possibly they have been quoted and escaped my observation. This gentleman, who is very rightly regarded as a sound authority, laid stress upon a sporting dog having small, round, hard feet, which he held to be a more certain test of endurance than any other point. "Rest assured, that the worst loined dogs with good feet are capable of more fatigue in stubble or heather than the most muscular and best loined, with fleshy 'understandings.' The most enduring pointers I have ever, seen hunted had more or less of the strain of the foxhound; but doubtless they were proportionately hard to break."

A variety of Pointer not much seen now-a-days is the black, or Scottish, which, of course, is free from any imputations as to the purity of his lineage. He is said to be all that one could wish. 



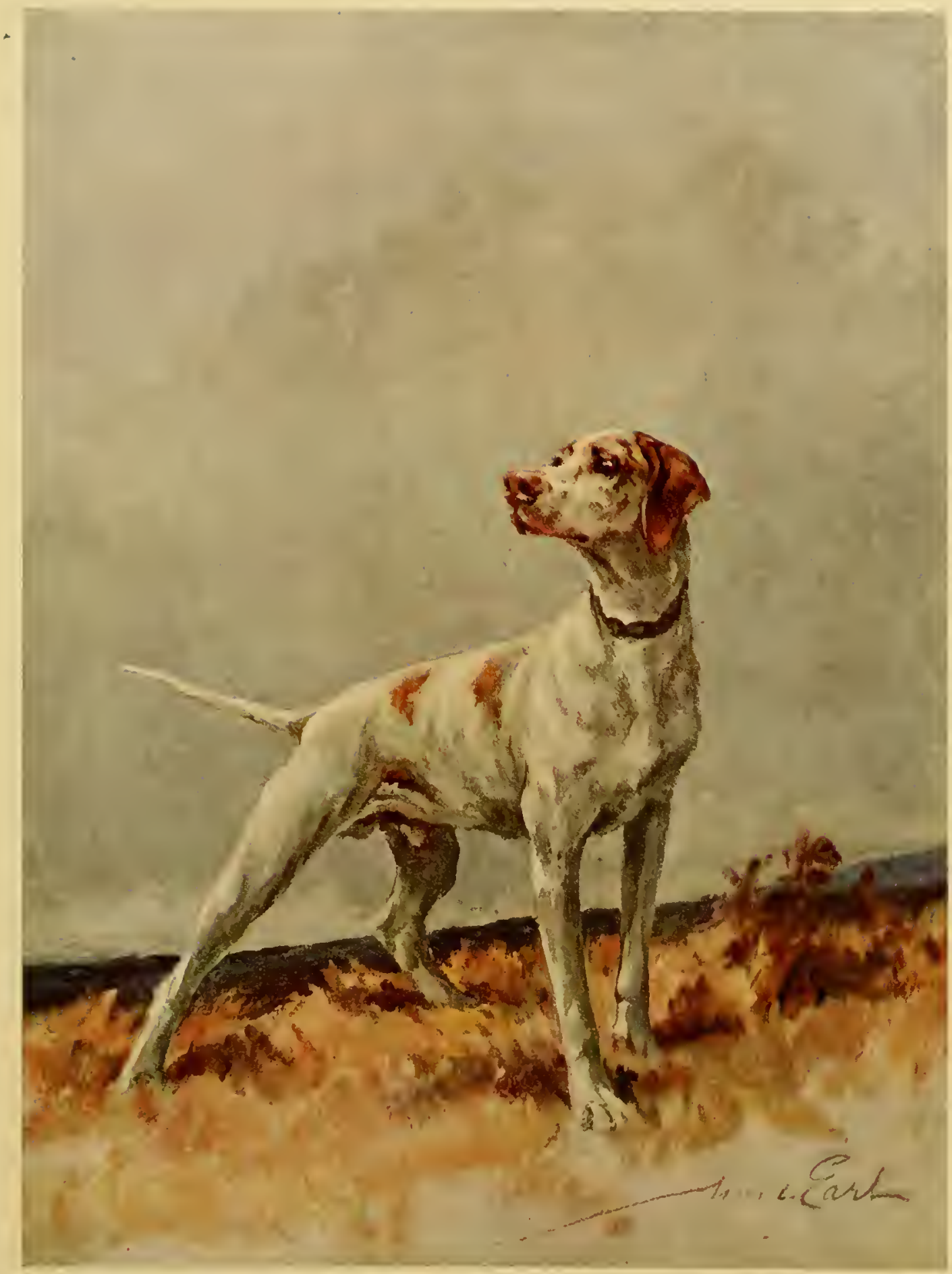



"... like greyhounds in the slips,

Straining upon the start."

Shakespeare-Heiliy $I$ :

GREYHOUNDS

"Spirituelle"

Ozwned by Mr. R. N. Stollery

"Rupert of Debate"

Owned by Mr. E. I'. Raynes 
THE、GREIHOUND

"I see you stund like grey/hounds in the slips, Straiming upsn the start. The game's afoot." KING HENRY $V$.

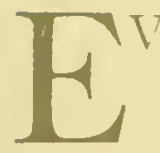

VER since primitive man was put to the necessity of plenishing the larder, dogs have been sub-divided into those that hunt by scent and those that pursue the game by sight. The most notable representative of the latter family is the greyhound, an ancient and persistent type discoverable in most parts of the world. Eastern countries furnish us with noble examples, which probably differ little in shape from the dogs used in the days of the Pharoahs, and from which, the chances are, our own were derived at some remote period. Malory thought it no anachronism to introduce the greyhound into his beautiful story of King Arthur and his knights. Does not the wife of Aries the cowherd explain how King Pellinore "took from me my greyhound, that I had at that time with me, and said he would keep the greyhound for my love." Malory was perfectly safe in his allusion, for centuries earlier carrings on monuments rescued from ancient Egypt, rude though 
they may be in their conception, have placed on record that dogs of this formation were common. It is not unreasonable to suggest that Egypt was the home of the race, whence they were distributed by means of cararans through the further East.

When we reach the Middle Ages we are on fairly solid ground, plenty of evidence being forthcoming as to the manner in which greyhounds were used. In France deer and wolves were hunted with them, but the fact that they were differently employed in this country leads Turbervile to write an original chapter upon the subject. "We here in England," he says, "do make great account of such pastime as is to be seen in coursing with Greyhoundes at Deare, Hare, Foxe, or such like, even of them selves, when there are neyther houndes hunting, nor other means to help them. So that I have thought it correspondent unto this myne enterprise, to set downe some briefe rules which I my self have seen observed in coursing with Greyhoundes. You shall understand then that we use three maner of courses with Greyhoundes here in England, that is at the Deare, at the Hare, and at the Foxe or other vermine." For coursing the deer, especially red deer, it was customary to divide the hounds into three ranks, viz., Teasers, Sidelays, and Backsets or Receytes. The duty of the Teasers, either a brace or a leash, was to start the quarry in a certain direction. Then, after some distance had been traversed, the Sidelays would be slipped, and being fresh, would probably take the deer. Failing 
these recourse was had to the Backsets, which were slipped in the face of the oncoming animal, "to the end they may more amase him." This does not sound very sporting, but our author assures us that a red deer was so powerful that it sometimes took four or five brace of greyhounds to pull him down. Coursing the hare was set down as the nobler pastime. As in the present day, so in Elizabethan England, it was not the kill that determined the merit of a greyhound, but " he that giveth most Cotes, or most turnings, winneth the wager." At modern coursing meetings, if two hounds are alike in colour, one has to wear a red, the other a white collar, in order that the judge may be able to distinguish. Turbervile remarks: "For the better decidyng of all these questions, if it be a solempne assembly, they use to appoynt Judges whiche are expert in coursing, and shall stande on the hilles sides whether they perceyue the Hare will bende, to marke whiche dogge doeth best, and to give judgement thereof accordingly: some use when their Greyhoundes be both of a colour to binde a handkerchef aboute one of theyre neckes for a difference. But if it were my Dogge he shoulde not weare the handkerchef, for I coulde never yet see any dogge win the course which ware the handkerchef. And it standeth to good reason that he whiche wareth the handkerchef should be combred therewith, both bycause it gathereth winde, and also bycause it doth parteley stoppe a dogges breath." Strange that the expedient of making both wear different coloured handkerchiefs was not devised until a later date. 
Turbervile says that the slowest greyhound that ever ran would overtake a fox, but owing to Reynard's propensity for showing fight it was desirable only to use old and crafty hounds. When a veteran caught a fox you would see him "thrust his forelegges backwardes and fall upon him with his chest: and so save his legges from bytyng when he taketh the Fox."

The three centuries or more that have elapsed since these words were written have probably witnessed few changes in the conformation of the greyhound, the hare still adopts the same subterfuges when chased, but, of course, the rudimentary rules which then regulated the sport have been developed into an elaborate code. Such modifications as have been introduced into the structure of the dog in the course of the ages have been due to the changes in the nature of the quarry he was designed to hunt. The earliest dogs, though possessing similar outlines, were no doubt stronger and somewhat more coarsely built, and as the hare became the sole object of the chase the tendency would be to breed for greater refinement, and consequently more pace. It is almost impossible to imagine a more gracefully built animal than the greyhound of the present time. 



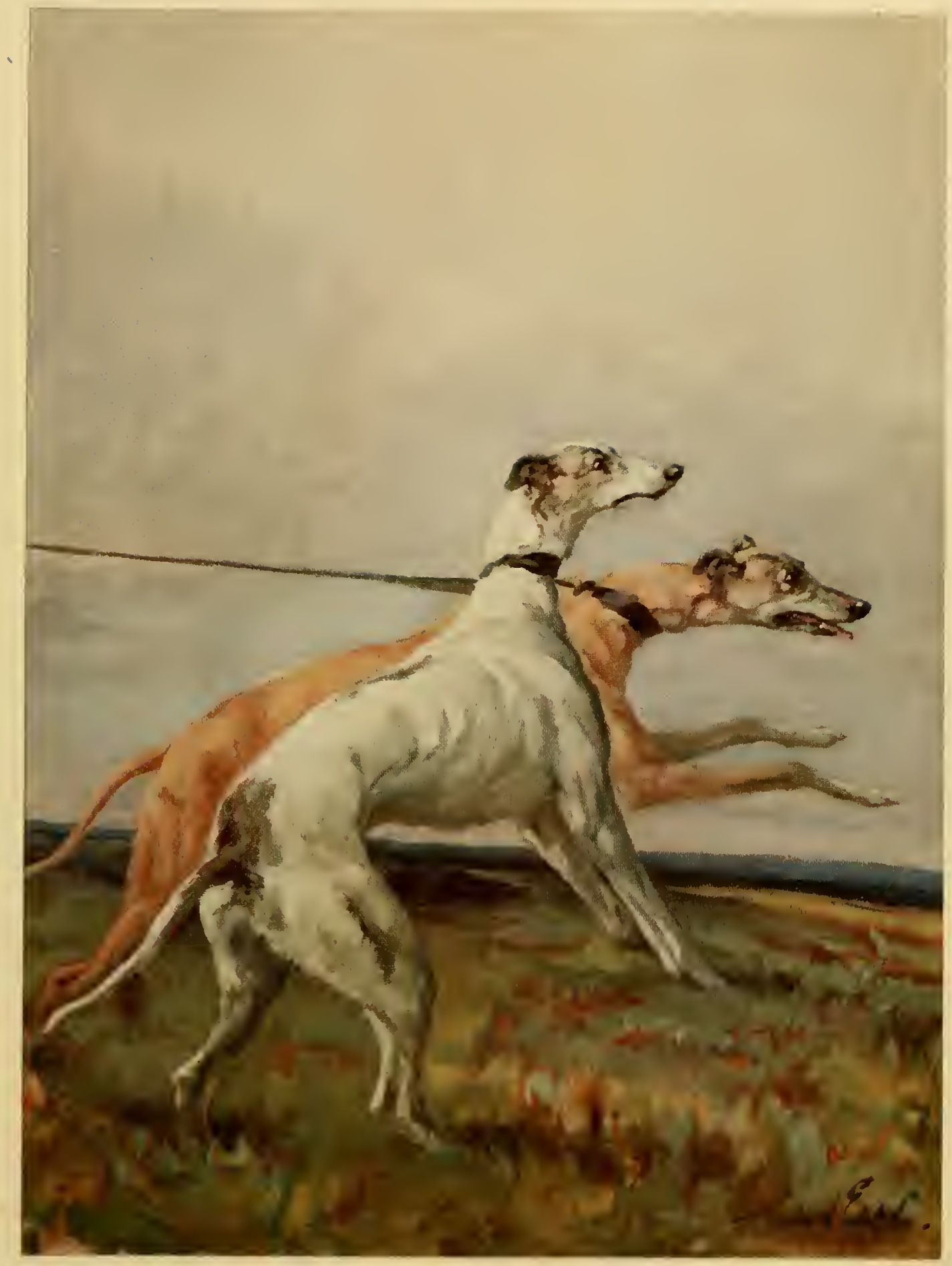



"Le temps s'en ia, le temps s'en ra, ma dame!

Las! le temps non ; mais nous mous en allons."

RONSARD.

PIRENEAN MOUNTAIN DOG "Milanollo Néthou"

Ounded by Lady Sybil Grant 


\section{THE PYRENEAN MOUNTAIN DOG \\ Sented by my side, At my feet, \\ So he breathed but air I breathed, Satisfied!}

Brow:Iivg.

$\mathrm{S}$ the heary train steamed into Willesden sounds of barking
directed me to the compartment in which the pup was travelling. This, the first excursion from the kennels in which she had passed the three and a half months of her young life, was an event to be signalised by signs of disapproval. Strange voices, stranger modes of locomotion, were disturbing and disconcerting, and my friendly accents but quieted her momentarily. The protest was renewed as we proceeded by another train to the home that was soon to be friendly and familiar. As for us we were anxious to see the small creature with such expressive vocal organs. When the hamper was opened the most delightful little Teddy Bear imaginable bounded out and proceeded to introduce herself. A mass of white Alufy down, with here and there a splash of lemon, eloquent dark eyes, and plump as the proverbial partridge. That was P.xdore as we first knew her. Time only served to strengthen and 
crystallize the early impressions. With manners as charming and irreproachable as her looks, before many diays had passed she had won all hearts, becoming an important member of the household. That wise head of hers held brains which led her instinctively to adapt herself to her surroundings, and fall in with the habits and wishes of the human gods who formed her little world. Visitors, though tolerated as necessary evils, were regarded with signal disapproval, heavy bark and bared teeth warning that no evil intent must be harboured towards the inmates of the house.

As Pandore grew older the downy coat was shed, profuse long hair taking its place in gradual transition, and she became more and more intelligent, until we agreed that we had never, among our host of canine friends, met one so sensible. None, too, could be more expressive. When on mischicf bent she displayed it with a roguishness of demeanour that earned absolution for the misdeed almost before it was perpetrated.

Greatly did she delight in a game of "catch as catch can" on the lawn with the children. Entering into the spirit of the fun she would romp round in endless gyrations, bushy tail cxtended to the full a few inches from hands ready to grasp, but she could calculate to a fraction, twisting and dodging with the art of a football player, until pity impelled her to pretend she could go on no longer. One could fill a book relating Pandore's escapades, 
but further recital might wcary. Let mention of her adventure with the garden hose suffice as an example of the rest. The curious serpentine length stretched out on the lawn interested her vastly, and when she heard the sisling noise made by the air escaping from the nozzle as the water came on down went her nose to investigate. A sudden jet full in the face caused a precipitate retreat, and now as the hose appears there is much commotion at a diplomatic distance.

These few words convey but inadequately the intelligence and charm of the Pyrenean Mountain dogs which Lady Sybil Grant is doing her best to acclimatise in this country. More delightful companions and trustworthy guardians could not be wished by the most exigent, nor is this surprising. For centuries they have lived in communion with their masters on the Pyrenean slopes, protecting the Alocks from bears and wolves, or human depredators. With the practical disappearance of the former animals their vocation to an extent has gone, while the inherited instinct remains. They are no common sheep dogs, used to round up the flocks. In their native land, the shepherd, following the old Biblical custom, leads his sheep to the green pastures on the mountains with the advent of spring, and there they remain until winter approaches. Time was when severe toll would have been taken of the defenceless creatures during the long nights but for the unceasing watchfulness of the faithful Patous posted at various points. 
As a French writer recently remarked, while by day the shepherd could exercise surveillance over the sheep, in the darkness this was impossible, and "il s'adjoignit donc un gardien de nuit fort et redoutable, dont les aboiements fussent assez puissants pour être entendus de loin et répétés par les échos de la montagne; dont l'odorat fut assez subtil pour suivre la piste des animaux sauvages et dangereux; dont l'intelligence fut assez développée pour comprendre que, la nuit tombée, il avait seul la garde du troupeau; enfin un compagnon dont l'affection et l'attachement pour les brebis fussent tels qu'il ne consentit jamais à se separer d'elles et qu'il exposât courageusement sa vie pour les protéger et les défendre, c'est ainsi que se constitua le vrai type des Pyrénéens."

What is the type of the dog thus highly praised? In size he is nearly as tall as a St. Bernard, without being quite so hearily built, and, although his head is less massive, it is still sufficiently large to be in keeping with the body. The expression conveys dignity and serenity as if conscious of power. The long white coat is marked about the head and in one or two other places on the body with brindle or lemon splashes. The whole appearance is that of a large powerful animal, remarkably active for its size, and capable of much endurance. 



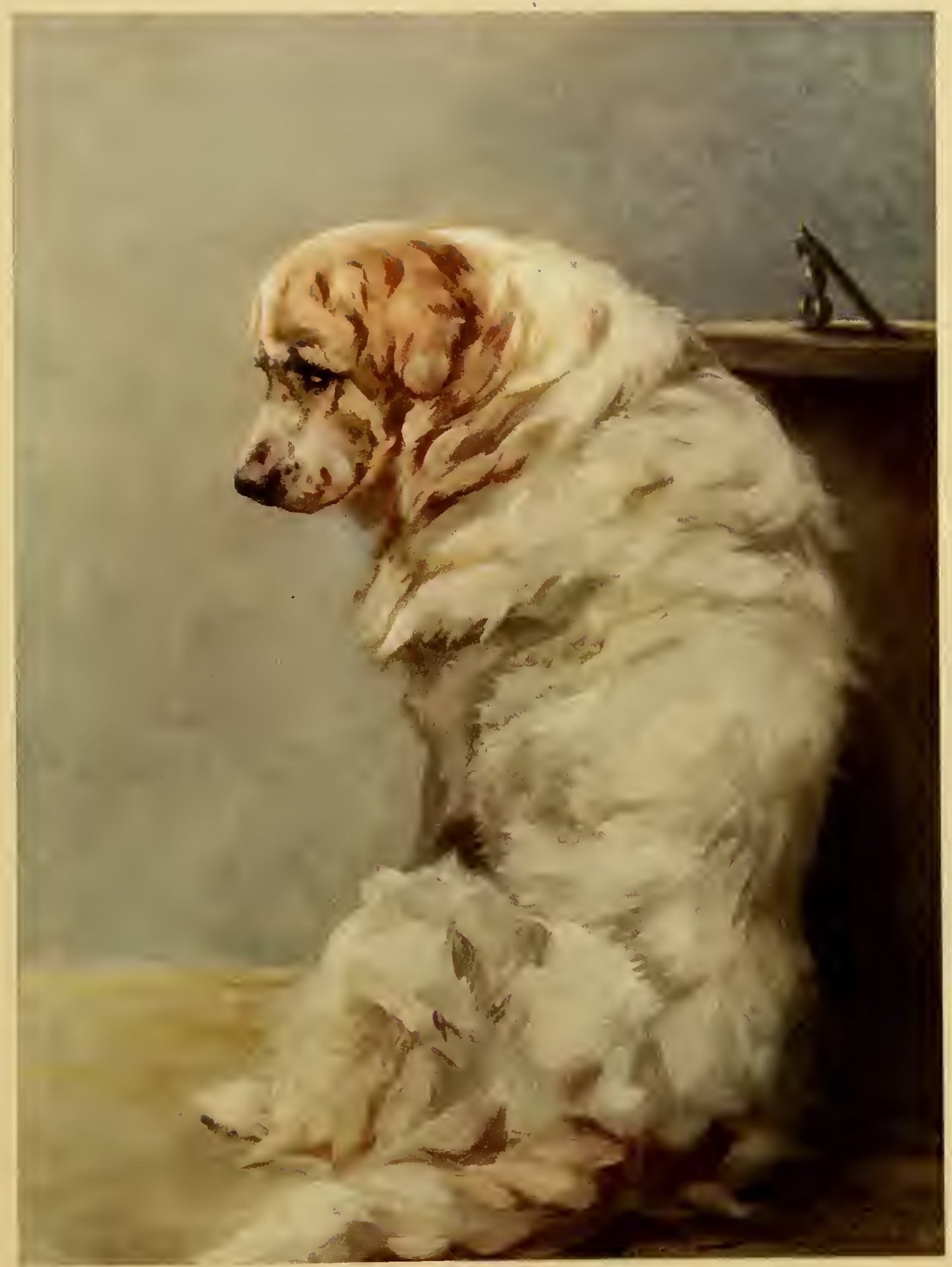



"These tre hated with a hate"

Found only" on the stage." . . .

Brron-Don Juan.

WELSH TERRIERS

"Ch. Longmynd Pypyr" \&o

"Longmynd Taffitus"

Owened by Mrs. H. D. Greene 


\section{THE WELSH TERRIER}

Though it appear a little out of fashism, There is much corre aud ralour in this IT'ishman.

King Henry $V$.

F one thing we may rest assured, the Prince of Wales will have no more devoted friend than the Welsh terrier Gwen presented to him by the miners of the Principality on his memorable visit to Carnarron Castle. She comes of a race, homely looking, perhaps, but staunch to the core. "By the mess, ere theise eyes of mine take themselves to slomber, ai'll do gude service, or aill lig i' the grund for it; ay, or go to death; and ai'll pay't as valorousiy as I may, that sall I suerly do, that is the breff and the long." A very happy thought of the working men to make such a gift to their Prince, and long may Given live to fulfil his behests. As far as disposition goes one terrier is practically as good as another, all sharing characteristics in common. Tafty is neither better nor worse than the others. Any kind of vermin that comes along is fair game for him, if he only gets the chance of using his 
powerful jaws. In the house he is a terror to tramps and all unauthorised intruders, his sharp ears at once detecting the advent of strange steps.

Your supercilious show man, who looks more upon the points of a dog than his inward qualities, may tell you that he lacks the quality of head seen in the fox terrier, and that his front is not always as true as could be wished. This may be perfectly correct, but on the other side one might point to his beautifully balanced proportions, and his naturally hard coat which demands little attention before he is fit to go into the ring. These, at any rate, are compensating advantages which should not be overlooked in striking a balance of his merits and defects. Greater length and fineness of head will come in time, and it is not usual to meet so many with bad front legs as we did a few years ago. There is no doubt that the breed is improving, and getting more widely distributed. For a town dog the black and tan jacket has much to commend it, soiling less readily than that of a fox terrier. Indeed, one could not ask for a dog that causes less trouble, and this surely is a consideration in the eyes of busy men and women.

Time was when men were found to declare that the Welsh terrier was nothing more or less than the old-fashioned black and tan wire haired terrier once common in England, but they hare retired worsted from the fray, and Welshmen are left in possession of 
the field. A satisfactory ending on the whole, for it would be a thousand pities to rob little Wales of her most typical contribution to the domestic canide. She has, too, her Springer and Cocker spaniels, both handsome dogs, but fewer in numbers, and some years ago she had also rough coated hounds, sturdy and hardy, as befitted the nature of the country in which they had to work. Unfortunately, they have practically disappeared.

The fact that the old English and the Welsh terriers displayed similar markings must not be used as an argument capable of being pushed to any great extent, for this is a colour that crops up in most brceds, and is therefore suggestive in many ways. Mr. R. I. Pocock, an authority to whom we must defer with respect, urges that it is potentially present in all, and from this fact he finds justification for the argument in favour of a descent from the wolf and jackal. A comparison will show that the tan on dogs is distributed, with the exception of the spots orer the eyes, in a manner precisely identical with the light markings on the wild animals. His conclusion is that the black and tan pattern is a nigrescent variation, saved from being completely melanistic by the pale areas turning tan instead of black like the rest of the body, tan or red in dogs, as in men and other animals, being an intermediate stage in colour between black and white. The point is interesting, especially to bulldog men, who debar a black and tan from winning prizes on the score that the colour denotes a bar 
sinister. We should rather prefer to consider it as a reversion to the natural marking.

In any case, we see no reason for questioning the purity of the Welsh terrier's lineage. Centuries ago, perhaps, he may have come from the general stock, but he has been a separate entity sufficiently long to win him a place as a product of the Principality. As was to be expected, before dog shows came into vogue, and with them the necessity of a general standard for every variety, a good many different types were observable. So they were in every other breed. This is inevitable until a family likeness has become fixed by united effort on the part of owners. Even this generic likeness admits of variations, for it is an easy thing to recognise the dogs coming from certain kennels, the skill of an individual stamping minor characteristics which others fail to catch and perpetuate, though working upon the same material. 



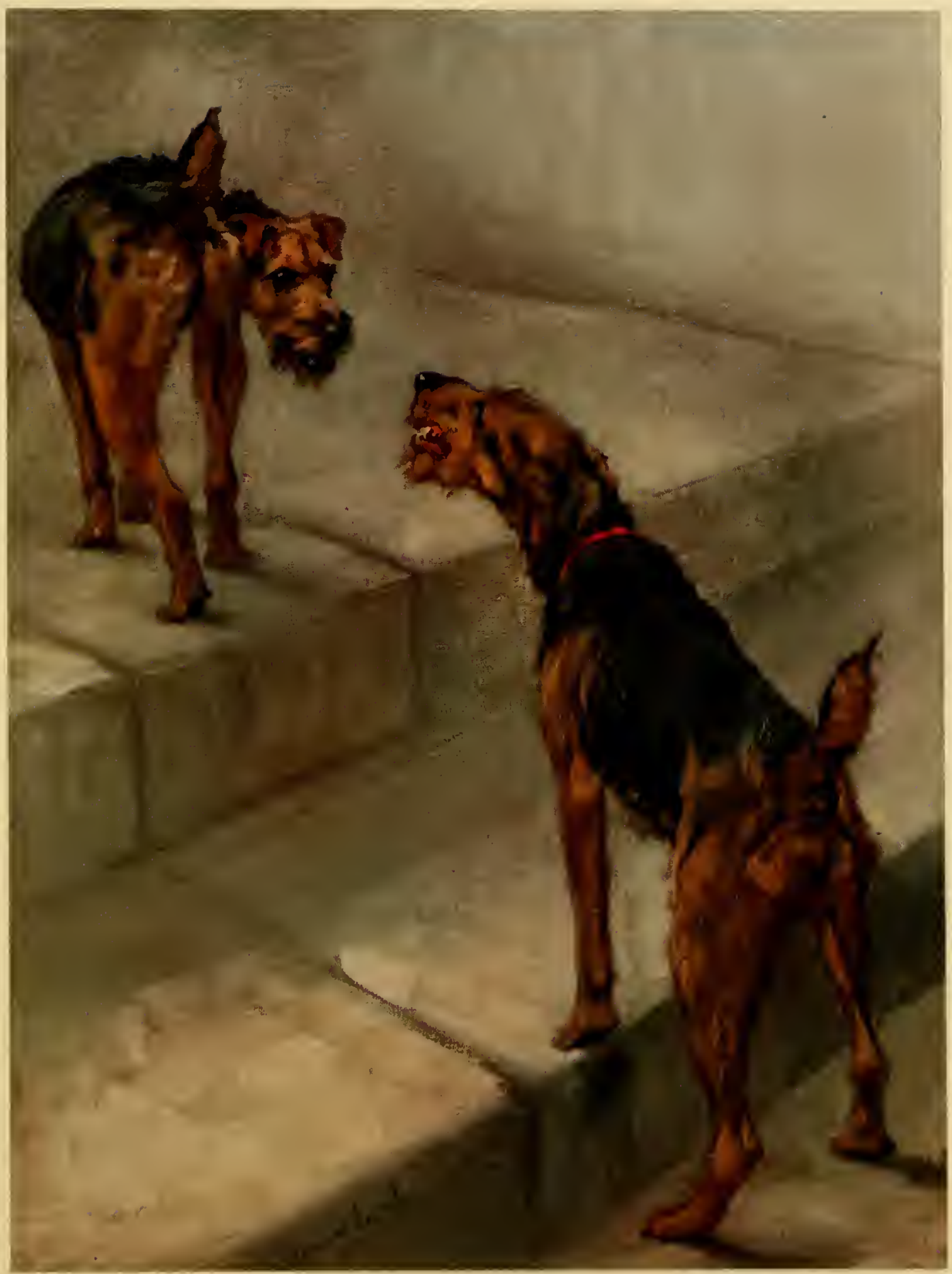



"Perhaps it wos right to dissemble your bov", But why" did you kick me downstairs?"

J. P. KembLe.

SCOTTISH TERRIER "Scotty"

Owined by the Hon. Mrs. Chorles Tufton 


\section{THE SCOTTISH TERRIER \\ "The labour we delight in physics pain." \\ MAсветн.}

CHORT legged, long bodied terriers have been indigenous to $\$$ Scotiand for more centuries than history records. Something comes to us from the second half of the sixteenth century, when the Bishop of Ross wrote of a scenting dog, "of low height, indeed, but of bulkier body, which, creeping into stibterraneous burrows, routs out foxes, badgers, martens, and wild cats from their lurking places and dens. Then, if he at any time finds the passage too narrow, opens himself a way with his feet, and that with so great labour that he frequently perishes through his own exertions." No matter what changes and modifications may have been since introduced by the skill of man, the bedrock fact remains that the Bishop's dogs were fashioned much on the lines of the aristocrats of the show bench to-day. Why Scotland should be prolific in terriers of the long and low shape, while England and Ireland are satisfied with those of a normal height is one of those things dificult of explanation. Theoretically, one would naturally imagine 
that the Scottish terrier, the subject of this sketch, the West Highlander, the Skye, the Dandie Dinmont, and the Cairn, would be better adapted for entering narrow earths than the fox terrier, but men of experience hold that it is not so much the length of leg which determines a dog's capacity for going to ground as his general shape, and a good fox terrier proves in a practical manner, to the refutation of logicians, that he is equal to the task.

As time goes it is but a brief period since the Scottish terrier emerged from the general ruck to take coherent shape, different from his fellows, but, if modern ideas are correct, we may gather some impression of what he was like by glancing at the Caim terriers the next occasion that serves, for these are believed by many to be the aboriginal terrier whence the others have sprung. Whether the Dandie Dinmont so originated or not I should not like to hazard a conjecture without going further into the matter. The name, of course, only came into being after Scott had written "Guy Mannering," but the dog was there before the book, and before Mr. James Davidson of Hindlee, who is persistently credited with being the personage from whom Dinmont was drawn, although Sir Walter has told us the character was a composite one. There have been people to declare that the Dandie sprang from some Eastern dogs imported into Scotland---an ideal which should not be inherently improbable, especially when we know for a certainty that the Egyptians some three thousand years ago had animals of this 
conformation. The rough coat would be Nature's method of compensating for the rigours of climate.

The Scottic is a stout hearted little fellow with plenty of pugnacity, qualities which stand him in good stead whon, in his native land, he is asked to turn the fox out of his lair in the rocks. The task is not always easy, but the labour in which he delights physics pain, and he proceeds with zest to bring Reynard to his master's gun, for in Scotland vulpicide is no sin. In the rough country hounds are useless, and foxes are to be kept under or they will become a nuisance. In the South we have no better occupation for this solemn looking little man than to win prizes for us on the show bench, or to act as a companion for us in our homes and on our walks. This he does with much fidelity, winning his way into our hearts by his pleasing manners. In habits he has a good deal of independence, which calls for care in his early training if we would have him all an inmate of the house should be. He has the merit, too, of attaching himself exclusively to master or mistress, without the spaniel-like fawning upon strangers which may at times be very provoking.

English folk are very acquisitive, annexing dogs from all parts of the habitable globe. Why they should have been so long in finding out the Scottish terrier is one of those things which cannot well be explained, and when they did decree that he was worthy of 
recognition they insisted upon foisting upon him the localised name of "Aberdeen," under which he still goes among many who do not keep themselves informed in kennel affairs. It was not long before Scottie became the rage; again we have to thank the shows. Now there is scarcely a street in which he is not to be met. In his finest form, the flower of fine breeding, and with points that put him in front of his fellows, he is worth much money, but in the more homely guise of one discarded as being " not quite good enough" his worth is not esteemed highly. Fortunately, the majority of people are not worried about type and club standards, simply asking for a dog that is intelligent, faithful, and biddable, who will assume his position as a suitable member of the household. If we can get one combining these features with a satisfactory pedigree perhaps on the whole it is more agreeable, the average man preferring to feel that he has the correct thing, though he may not know anything about it in reality. It is perfectly true, too, that breeding is as apparent in a dog as it is in a horse or a man. There is an indefinable something that betokens class. 



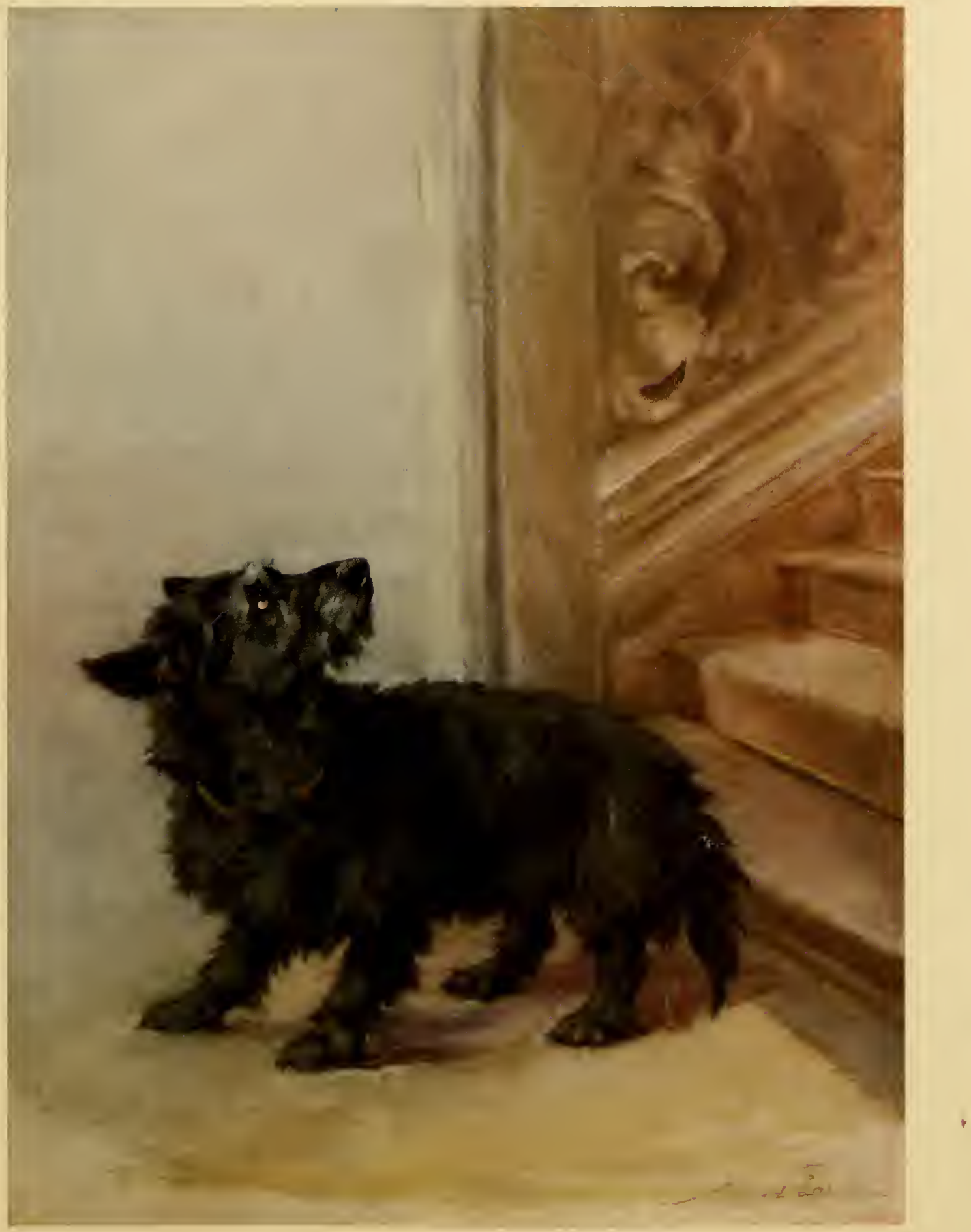





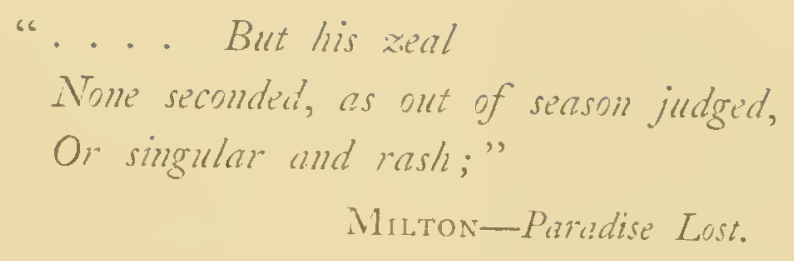

SEALTHAM TERRIER "Peer Gynt"

Oand by Mr. Hary Jones 


\section{THE SEALYHAM TERRIER}

"These be but jests to that he shall do: he shall prove a noble knight of prowess, as good as any is living, and gentle and courtions, and full of good parts, and passing trite of his promise."

MALORI.

NE might have thought that we have terriers in abundance, and of sufficient diversity in shape and size to gratify all tastes, and cope with any kind of work that may come along. England, Scotland, Wales and Ireland have all furnished their quota, yet the late Captain Edwardes of Sealyham, Pembrokeshire, a kinsman of the present Lord Kensington, was not altogether satisfied with those already in existence. Deeming that a combination of the rirtues of several old breeds would be useful, some seventy or more years ago he addressed himself to the task of bringing another race into being. Primarily, it is to be presumed, he sought for courage and stamina in a small body. He wanted a terrier that would hold fox or otter, or stay underground with Mr. Brock until the diggers could reach him. Although as the world goes serenty years make 
but a brief period, these seven decades have been sufficiently long to obliterate the evidences as to the dogs used by the gallant Captain for his hybridising purposes. The inference is, from the shape and the occasional silkiness of the hair on the top of the head, that the Dandie Dinmont played a leading part; from the pluck and colour, as well as the stamp of the terriers of thirty years ago, that Bull Terrier blood is also prevalent. Authorities, however, are by no means agreed as to the Dandie Dinmont, Mr. Fred W. Lewis, for instance, writing: "This is all a matter of speculation, and I am disposed to think that the Welsh cur or cattle dog---a very sturdily built, short, crooked legged dog, used by cattle drovers---was the means adopted to shorten the legs of the Sealyham terriers. The cur in most cases possessed plenty of pluck, and an inherent taste for hunting. That the majority of Sealyham terriers were very crooked in front is a well known fact, which can be verified by those of us who are old enough to remember Captain Edwardes and his dogs."

In his pursuit of gameness Captain Edwardes had inevitably to meet with disappointments here and there, not all the puppies he bred conforming to the exacting standard which he had set up in his own mind. Like the sensible man he was he decided that if his object were to be achieved, no pusillanimous dog must be allowed to live and aid in perpetuating the race. So it came about that a certain number had to be put under from time to time, with 
the result that the survirors more nearly approximated to the requirements of their owner. If all breeders were content to take measures as drastic their end would be attained with more ease, no matter what it might be, but wretched pecuniary considerations intrude themselves to prevent such a policy of perfection becoming common.

Naturally, a certain number of the terriers in course of time passed beyond the bounds of the home kennels into other hands, and when Captain Edwardes' strain came to an end on his death in the serenties, enough were in being to ensure the perpetuation of the race. Unfortunately, those that remained were not bred from with as scrupulous care as was exercised by the founder. A few were kept on by the Captain's niece, Miss Borrowdaile, the remainder being distributed far and wide. Until the last few years, the Sealyham had but a local reputation, occasionally one appearing at shows in South Wales, without attracting much notice. About cight years ago a dog called Peer Gynt, bred by Mr. G. H. Morton, became prominent, experts considering that he approached more nearly than any other to Captain Edwardes' ideal, as he had the type as well as a reputation for subterranean exploits. From him have sprung many of the terriers which are to-day being exhibited with success, and he has rarely been beaten in the show ring. His purchase by Mr. Harry Jones for $£ 50$ at the Kennel Club show of I 910 marked an epoch in the history of the variety. 
It was only necessary for Sealyhams to be seen in order for them to gain admirers, and in the course of quite a short time they have become one of the features of any large show. Opinion is agreed that Sealyhams are useful-looking terriers, hard bitten, and fully capable of acquitting themselves as staunchly as their supporters aver. That the type is not yet altogether characterised by uniformity is a matter for no surprise, and any differences that are apparent can easily be adjusted. All that we can hope is that in the future he will remain in the right hands, and not be made a pawn in the game of commercialism, or be allowed to degenerate into a carpet knight.

A reference to Miss Earl's picture will give one a better idea of the style of terrier required than any pen portrait can convey. It may be noted that he should have a long and powerful jaw, squarer than that of the fox terrier. The drop ears are V-shaped, and the eyes, set wide apart, are round and large, of a dark brown or dark hazel colour. The broad chest should be well let down between the forelegs. The body is long and supple, ribs well sprung, hindquarters very powerful. The legs should be as short and straight as possible, and the feet round and cat-like. The colour is mainly all white, or with lemon, brown, or badger-pied markings. 



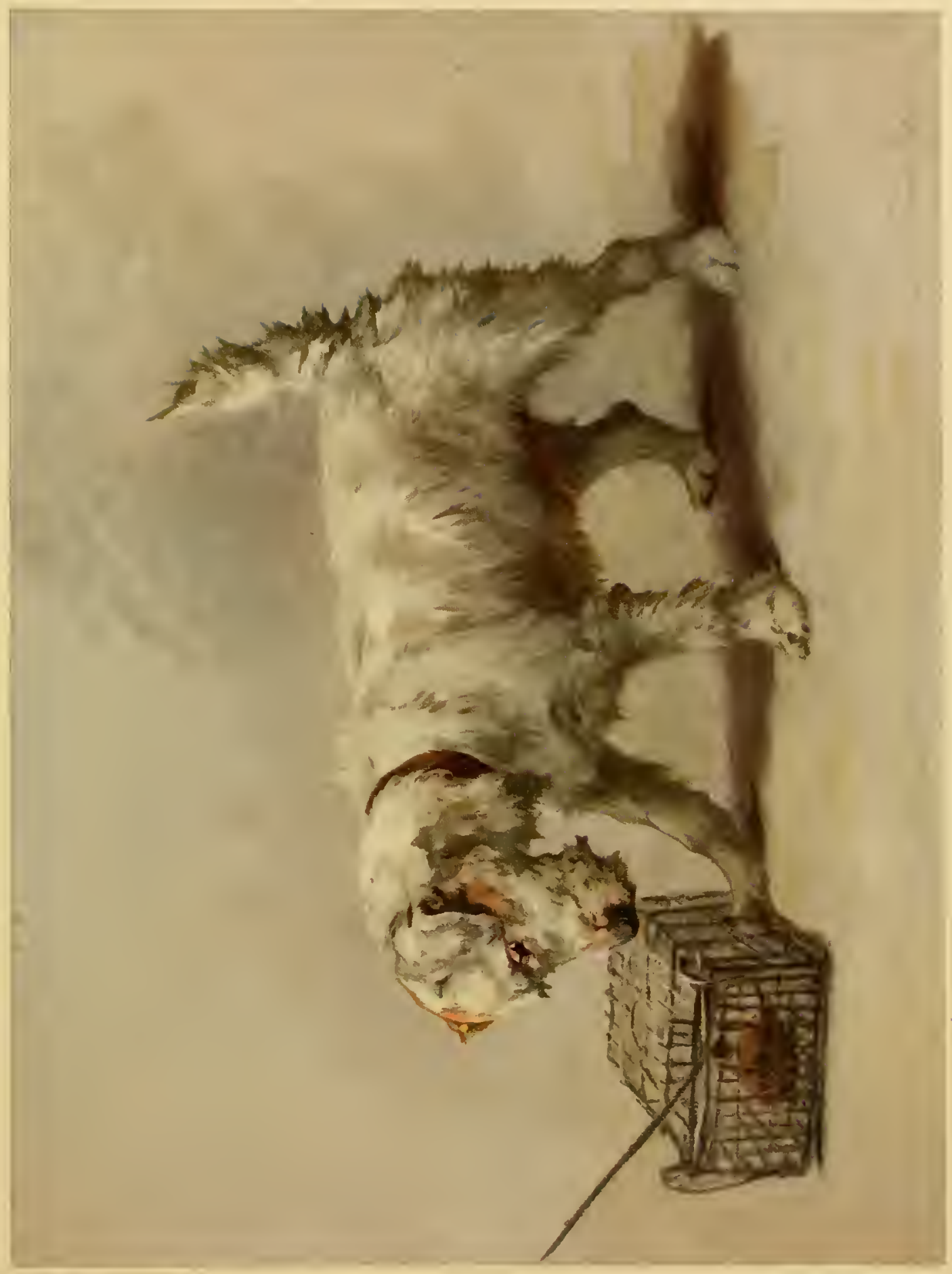



"Shum, shun the bowl, that fatal facile drink,

There may be silier in the blat-black, all I know of is the iron and the gall."

RIDYard Kipling. 


\section{THE FOX TERRIER \\ For huntin' the rarmin reet clever was he, And the house fier a rabbers his bark wiad keep free, Conld baith fetch and carry; conld sit on a stool, Or, when frisky, wial hunt water rats in a pool. IFeel-bred Ciappy, fomons au'd Cappy, Ciappy's the dog. Talli-ho! Talli-ho!}

DOG that's fit for anything, badger or fox, rats or rabbits, 1 the Fox Terrier is of universal distribution. We meet him on the show bench, spruce and well groomed, exchanging wordy warfare with his neighbour; running with the hounds, ready for any work that may chance, or at his master's feet in the smoking room when the doings of the day are recounted---no matter where he may be, he will make himself at home, in cottage or in hall, so long as there is sport afoot in the daytime, and a dry bed to lie upon at nights.

Talk about terriers takes us back many centuries. The worthy Dr. Caius, founder of the college at Cambridge, tells us about them, and a few years later we have old Turbervile's dissertation in 
his "Book of Hunting." The worst of it is, we do not know how much is Turbervile, how much Du Fouillot, whom he translated, and how much still earlier writers from whom the Frenchman borrowed. What we do know is that our ancestors dug the fox and " badgerd" after the manner in which we dig them now-a-days, and that they used terriers in the sport. We have also evidence that terriers of various kinds existed, Turbervile writing "You must understand that there are sundrie sortes of terriers, whereof wee hold opinion that one sorte came out of Flaunders or the low Countries, as Artoys and thereabouts, and they have crooked legges, and are short heared moste commonly. Another sorte there is which are shagged and streight legged; those with the crooked legges will take earth better than the other, and are better for the Badgerd, bycause they will lye longer at a rermine; but the others with streyght legges do serve for twoo purposes, for they wyll Hunte above the grounde as well as other houndes, and they enter the earthe with more furie than the others : but they will not abide so long, bycause they are too eagre in fight, and therefore are constrayned to come out to take the ayre: there are both good and badde of bothe sortes."

True, good sir, even unto this day there are good and bad of both sorts; and there are good and bad sportsmen also, but I doubt if our modern Nimrods are sufficiently luxury-loving to take with them air cushions when they go badger digging. Turbervile's 
"Lords or Gentlemen which will follow this pastime" were admonished to have half a dozen mats upon which to lie as a protection against the damp earth, and "some used to carrie a windbed whiche is made of leather strongly sowed on all the foure sides, and having a Pype at one of the comers to blowe it as you would blowe a Baggepype."

It was probably somewhere about the beginning of the last century that the fox terrier blossomed from the nondescript stage, into definite shape. When Peter Beckford, cousin of the author of "Vathek," published his classic work on hunting a hundred and thirty years ago, there were at least black, white, and red terriers, and doubtless also variants on these colours, as little trouble seems to have been taken over the breeding, so long as the dogs were staunch, and capable of doing the work for which they were required. The present day aristocrat of the show bench has in him the blood of a long line of ancestors who have done yeoman service in their time, and, though he may differ in details, the general conformation remains much the same. Of course, he is better looking, the signs of race being more apparent, but whether or no he is any the worse adapted to fulfil his duties is a subject of endless controversy into which I need not enter in this place. The chief point to consider in this connection is the family rather than the individual. The owner of a dog worth some $£_{0} 500$ is not particularly keen about letting him run any risk of injury, but if 
his collaterals and progeny are worthy knights of the field, we should not worry about that. The main thing is to see that the points which the exhibitor strives to produce are not incompatible with working qualities. The aim of these gentlemen is to breed a symmetrical dog which shall be built much upon the lines of a hunter, and it is necessary that he should have a hard coat fitting him for duties in all weathers. The markings, mere externals, are immaterial, although it is a common thing to hear a novice enlarge upon the beauties of his terrier because he happens to have some nice even black and tan upon his head. Such considerations as this should be left to the "fancier" pure and simple. In a toy it is perfectly legitimate to lay stress upon colour and marking, for his main object in life is to please the eye, but in a working dog conformation and stamina should have precedence over everything else. Fire and courage are essentials, without which a fox terrier, or a terrier of any kind, is but a sorry impostor, suitable only to adorn a cushion by the fireside. There may be individuals who prefer this kind of creature, but happily few are to be found in the ranks of terrier breeders. 



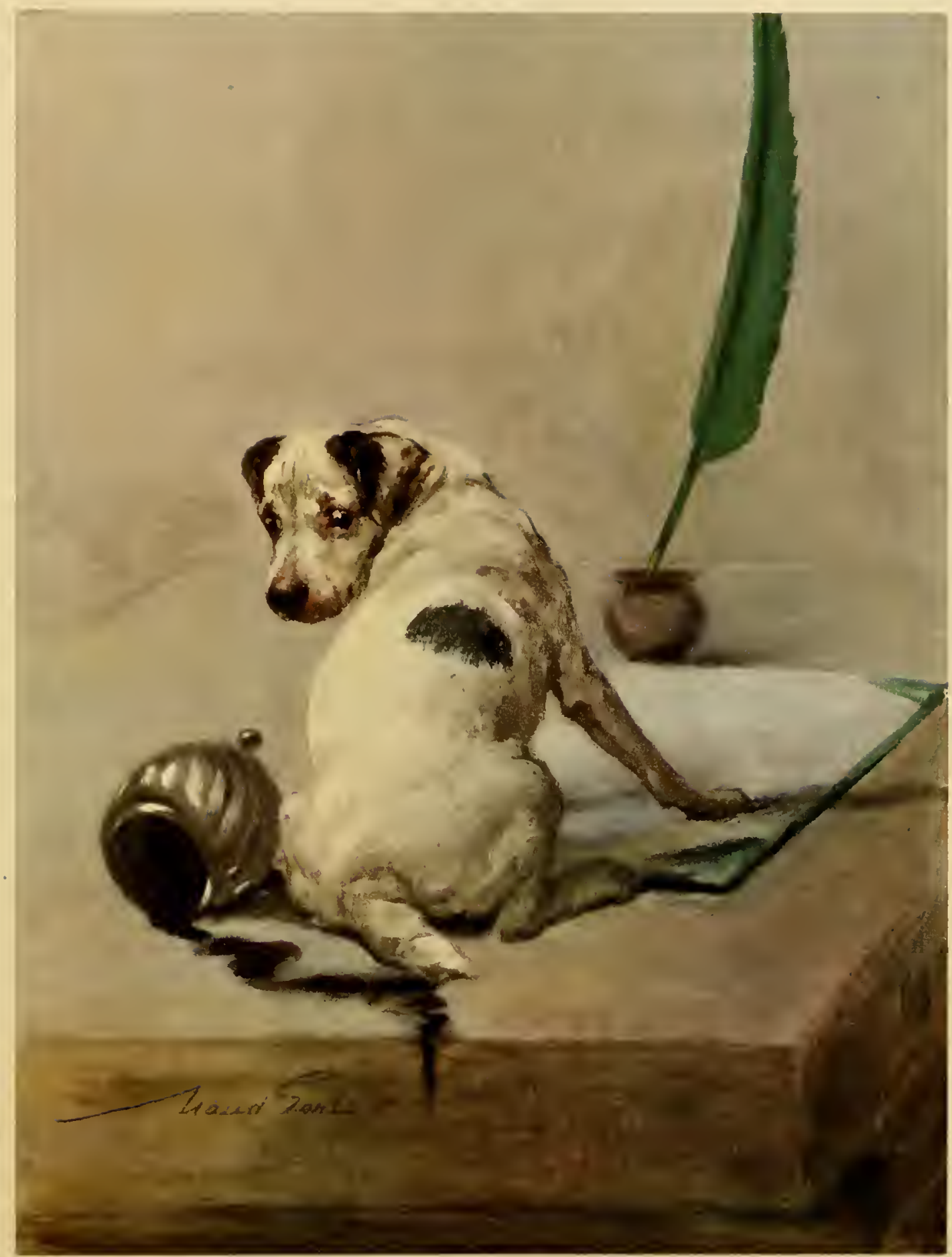



"Alas! they had be'll firinds in youth,

But whispering tongues can poison truth."

Coleridge-Christabe?

IVEST HIGHLAND IVHITE TERRIERS

"Tissie" \&o "Tamner"

Owned by Mrs. Lionel Faudel Phillips 


\section{THE WEST HIGHLAND IVHITE TERRIER \\ "He was a gash an" faithfill tyke, As ever lap a sleugh or dyke, His honest, sonsie, baw'nt face, Ay gat him firiends in ilka place."}

Burvs.

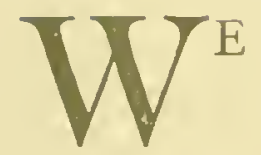

E have already mentioned Scotland's terriers, the tale of which, however, is incomplete without some references to the wiry coated white tyke, the West Highland White terrier, whose winning ways have got him friends in every place. Though little known south of the Tay until quite recent years, he is now highly favoured of fortune, few varieties of terriers enjoying a more genuine popularity. In his native country, the wild land of Skye and the western parts of Inverness-shire, he has proved his worth for generations, none coming to us with sounder credentials. Foxes, badgers, otters are his sworn foes against whom he has waged unceasing warfare, just as his Scottish terrier cousin has done. Mrs. Cameron Head has well explained his vocation: "In the old days, before deer forests extended orer such a large area in the Highlands, and the land was principally under sheep, fox hunters 
used to traverse the country from one sheep farm to another, and days were organised for attacks upon special cairns in which foxes were known to be. The fox hunter himself kept a strong, varmint breed of terrier, and the shepherds and keepers on each estate did the same, so that when an onslaught was organised upon Reynard the stiffest and hardest duty fell to the terriers, for they were expected to go into the cairns and tackle the inmates single handed, deep in the bowels of the rocks, where no man, and indeed no other dog, could enter because of the narrowness of the passages. The terrier generally selected for this stern conflict was not the white one, who was regarded as weaker than his brethren with more colour in their coats---though we think that in this his breeders did him an injustice."

In those days sandy and brindled dogs were looked upon as the hardier, but one or two families in the Isle of Skye made a habit of preserving the white or sandy and destroying the brindles. Among these were the Macleods, Lairds of Drynoch. As a daughter of Norman Macleod, born in 1800 , was wont to declare that her father and grandfather kept terriers of this colour, we are taken back into the early part of the Eighteenth century. This seems conclusive, but so much conflicting evidence has been brought forward during the last two or three years that it is difficult to unravel the truth from amid the tangled threads of controversy. Probably most of the modern dogs are largely indebted to terriers 
from the mainland. Colonel Malcolm's strain at Poltalloch, for instance, has existed for a long period, and Brogach, whose name figures in so many fashionable pedigrees, was of the breed taken to Portrce in 1896 by Mr. James Mackintosh. They were only called "white" by courtesy, the real colour being a cream. For practical purposes this is near enough, the pure colour being obtainable by selection, and capable of being more or less permanently established in the course of a few generations.

Many of the characteristics of the West Highland White Terrier are similar to those of the Scottish. He is dead game, a glutton for work, and he, too, is exclusive in his attachments, with a dignity of demeanour that is particularly charming. He has not the demonstrative fussiness of some of the terrier family, for which reason he is a welcome member of the household. In his education firmness is needed to orercome a highly strung nervousness, which is only accentuated by correction. Indeed, a severe rating or a thrashing will make him for ever suspicious. Treat him with kindness tempered by a decisiveness that marks you out as his master, and he will be your devoted servant.

So great has been the demand for these dogs that puppies, even of moderate pretensions, command a high price, and the best are capable of fetching several hundreds. Mr. Viccars' Champion Kiltie was purchased by an American for 400 guineas, and others 
have made half that sum. Time being young, so far as attcmpting to breed in conformity with a certain standard is concerned, we must not be surprised to see still some divergences in type, one judge preferring one kind and another another. One thing is positive---the dog must not be bred on the lines of a Scottish Terrier, although when he was first introduced the idea was prevalent that he was but a white edition of the older dog. The West Highlander is smaller, somewhat shorter in the back, and with legs a trifle longer. He is altogether more active. In the head, too, differences may be detected. This is broader in skull, and has a more clearly defined stop beneath the eyes, and the muzzle is not so long and powerful. His coat should be longer than that of Scottie---about two and a half inches long to be exact---and it must be hard and wiry without any suspicion of curliness or waving. The shaggy hair on the face prevents earth and sand getting into the eyes when he is busy underground in his efforts to dislodge fox or badger. A profusion of soft undercoat has wet-resisting value. Finally, a good terrier must move with plenty of liberty. 



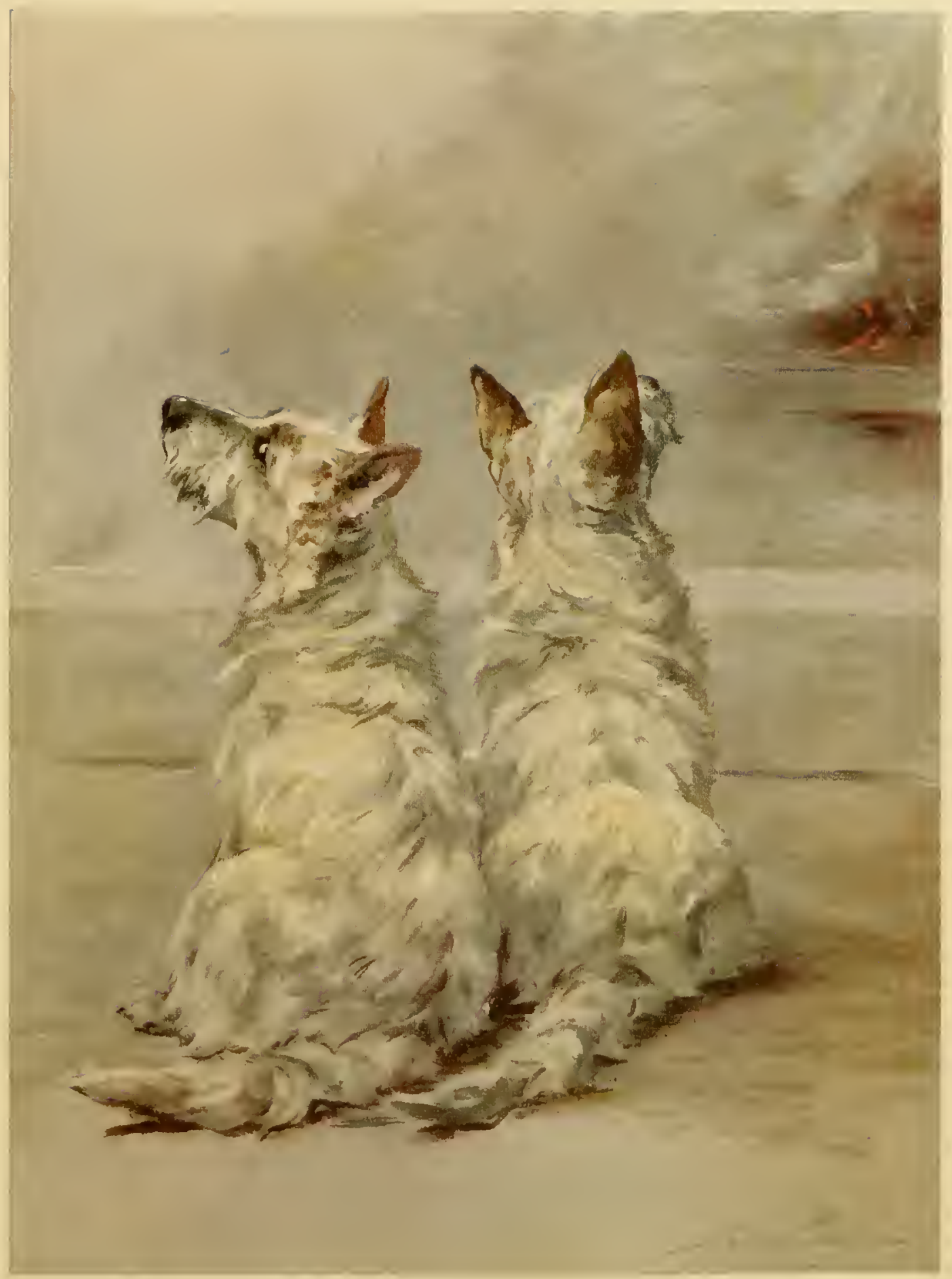



"Some there are who do thus in beanty love each other."

Maeterlinck

MINIATURE BULLDOGS

"Champion Chevet Punch" \&o "Chevet Daisy" Orened by Lady' Katheen Pilkington 


\section{THE MINIATURE BULLDOG \\ "IIhich I have a small forour to ask you, \\ As concerns a bull-pup, and the same,- \\ If the duty would not overtask youl,- \\ fou would please to procure for me, GA.ME; \\ And sent her express to the Flat, Miss,- \\ For they say Tork is famed for the breed, Which, though words of deceit muy be that, Miss, \\ I'll trust to your taste Miss, indeed."}

Bret HARTe.

THE rage for bantamising things has occupied the minds of 1 men for countless generations. Japan has sent us dwarf trees and bantam fowls. Great dames of Egypt, and, later, of Greece and Rome, had their toy dogs, some of which were miniature editions of larger varieties. We, too, have pursued the same custom, with our toy spaniels, toy terriers, and now miniature bulldogs. You must not call these little midgets "toys" unless you would offend the susceptibilities of those who farour them. The objection to the employment of this word in such a connection is perfectly valid, for, in the real sense, the miniature bulldog is not a toy at all; he is merely a replica in little of the bigger brother from whom he has sprung. His lineage is as pure, his 
pretensions to breeding as justifiable. Probably if the Fiench bulldog had never been imported we should have heard nothing of the miniature. Somcwhere about 1893 the late Mr. G. R. Krehl exhibited a team of the small Parisians under the name of French Toy Bulldogs, but it did not take long to see that, whatever may have been the origin of these dogs, in the interrening years they had departed very materially from the accepted bulldog character. The wide, upward sweeping underjaw of the national breed was absent, and the cars! In the eyes of the orthodox these indispensable members were ererything they should not be. The erect, commonly termed "tulip" or "bat" ear, surmounting the skull of an ordinary buildog would be an enormity, so after much disputation the rival schools wisely decreed to go divergent ways, and to have their respective favourites christened Miniatures and French. Now that matters have settled down it is incontrovertible that this was the most sensible way out of the difficulty. Light weight and French bulldogs may all have sprung from the English Midlands, but, as a decade or two will suffice to establish a new type, by the time they were expatriated the Gallic dogs had departed in essentials from the type desired by English breeders. Our French friends, unfettered by tradition, and without the correct stamp in their minds, had evolved a creation of their own. There let it rest.

The intrusion, however, stimulated an endeavour to revive in 
its purity the small bulldog which was common enough in the sixties. The task presented so many obstacles that surcly none but ladies, with all the enthusiasm and perseverance of their sex, would have ventured upon it. Lady Kathleen Pilkington and Mrs. Carlo F. C. Clarke, staunch from the beginning, are still pursuing their object with admirable pertinacity, and, what is more, they are succeeding in converting the scoffers to the view that a miniature edition of the big dog is a possibility. Every year the type is improving, and the dreadful unsoundness that was at first so common is being extinguished. Miniature bulldogs can now walk instead of crawl, and the backs are better, although we still meet some that dip too much behind the shoulders. Early experiences almost warranted the taunt: "Thou call'dst me dog before thou hadst a cause," a caunt which is no longer justified.

No one will pretend that the miniature bulldog is good for anything other than companionship. He could not throw an ox if we wished to set him to such barbarous work, but if we want an inmate of the house of manageable size and reasonable proportions, with the looks and attributes of a larger animal, we have one ready at hand. They are not easy to brecd. If they were, balf the interest in the pursuit would vanish at once, for most of the pleasure in a hobby consists in having some obstacle to overcome. Lady Kathleen Pilkington once wrote: "To cultivate them has been an intense interest, and a very great pleasure, for 
they are a most fascinating little breed, and one which anybody with even a minimum of time and money could do a very great deal worse than devote themselves to, for both as show dogs and as pets they repay one a hundredfold, when one has the good luck to be successful, and a great many times when one hasn't. . . . To keep them merely as pets is a real pleasure, as few dogs are better tempered or more affectionate, and with ordinary care they are healthy and strong." 



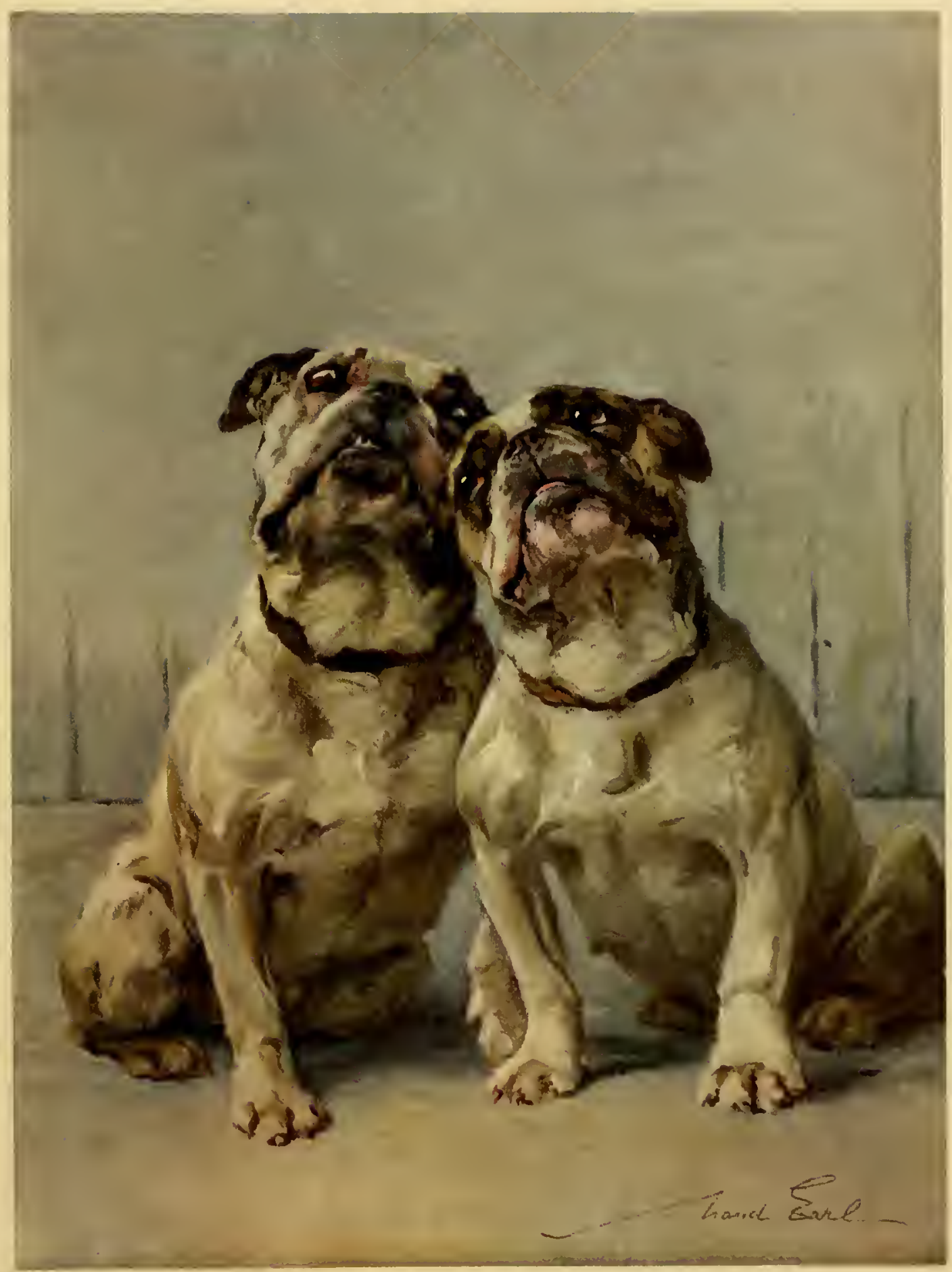



"I have no urns, ws dusty monuments, No broken images of ancistors,

Wanting an ear or mos: no forged tables Of long descents, to boast false honsurs from."

Bex Joxsox.

BULL TERRIER "Buller"

Oained by Mr. Darissm 


\section{THE BULL TERRIER \\ "That island of England breeds wery caliant creatures." \\ King HENRY V.}

CTAUnChest of the staunch, the Bull Terrier will fight to $\$$ the death in the service of one he loves. Although of high courage he is not necessarily a seeker after quarrels with others of his kind, but when he has entered upon one he follows the advice of Polonius, so bearing himself that the opposed may beware of him. There is a story related of a Dalmatian whose duty it was to follow his master's carriage to the station every morning. At a certain house on the road was a surly retriever, who constantly made the unhappy creature lament that he was ever born a dog, what time his owner cursed his pusillanimity. One day this gentleman confided his trouble to a friend who kept a bull terrier. "We will soon settle the retriever," was the reply, and next morning the terrier, with artistic black spots dotted about his body, made the journey instead of the Dalmatian, and gave the bully such a bad quarter of an hour that for ever after he held his peace. 
Fifty or more years ago, one regrets to record, the bull terrier was a very disreputable fellow, his arocation being dog fighting, badger baiting, and ratting. In the middle of last century no undergraduate of sporting proclivities had completed his education until he could appraise the merits of one of these dogs. We all remember how Charles Stewart Calverley traced the metamorphosis of the Freshman, whose education grew by degrees until he

Learned to work the wary dog-cart

Artfully through King's Parade:

Dress, and steer a boat, and sport with

Amaryllis in the shade:

Struck, at Brown's, the dashing hazard;

Or (more curious sport than that)

Dropped, at Callaby's, the terrier

Down upon the prisoned rat.

Gone are these days, "good old times," they were called, when by some strange perversion baiting an imprisoned animal was miscalled sport. We are no less sporting to-day, but our tastes have assumed a healthier form, and it has become a wholesome law that the object of our pursuit shall have a decent chance of making good his escape.

The prejudices excited by the earlier associations of the bull terrier were not easily orercome, and it was many years before he received the entrance to decent society. Doubtless dog shows had much to do with his rehabilitation, people coming at last to 
recognise his sterling qualities, although the practice of cropping the ears, continued until 1895 , kept him from winning his proper place in popular regard. However desirable this form of mutilation may have been in the fighting era, the suffering involved was afterwards wholly unnecessary, and the decision of the Kennel Club to put an end to it was one of the wisest things this body has ever done. The belief of the pessimists that the bull terrier had received his death blow has not been justified by results. At first, it is true, the natural ear was an eyesore, much detracting from the smartness of appearance, but the new generation, having become accustomed to the present style, sees little of which to complain, and contents itself with the dog as he is.

Not only are classes at shows well filled, but the ordinary man, who never dreams of exhibiting, is coming to see that if he would have an ideal guard and faithful companion, not too large for the house, and yet with sufficient weight and pluck to tackle a burglar, he could not well do better than buy a bull terrier. The old dogs were of all sorts, sizes, colours and types, little uniformity being observable, but now we have a shapely animal, with an air of breeding and class. Note the power and symmetry of his body, a combination of agility and gracefulness. He is as clean built as a bit of sculpture. The small eye may be a stumbling block at first, but even this, on examination, becomes a fitting complement to the shape of the head, and we would not have it otherwise. 
One undoubted drawback is the tenciency to deafness inherited by so many. Why the pure white dog should be subject to this defect would need an explanation of too scientific a nature to make it admissible within the scope of this chapter. It may be noted, however, as a matter of interest, that the presence of one or two dark marks on the skin, not apparent in the coat, is sufficient to maintain the hearing unimpaired. The correlation between the total absence of pigment and the non-existence of the sense of hearing has frequently stimulated the investigation of scientists. The same phenonomen is manifested in the feline race, white cats with blue eyes almost invariably being deaf. The curious thing is that if one of the eyes is of a different colour the hearing is not defective. Darwin's omission to speak of the bull terrier when writing upon this topic is not surprising, considering that the all-white dogs were not common in his time. They were a later product. 



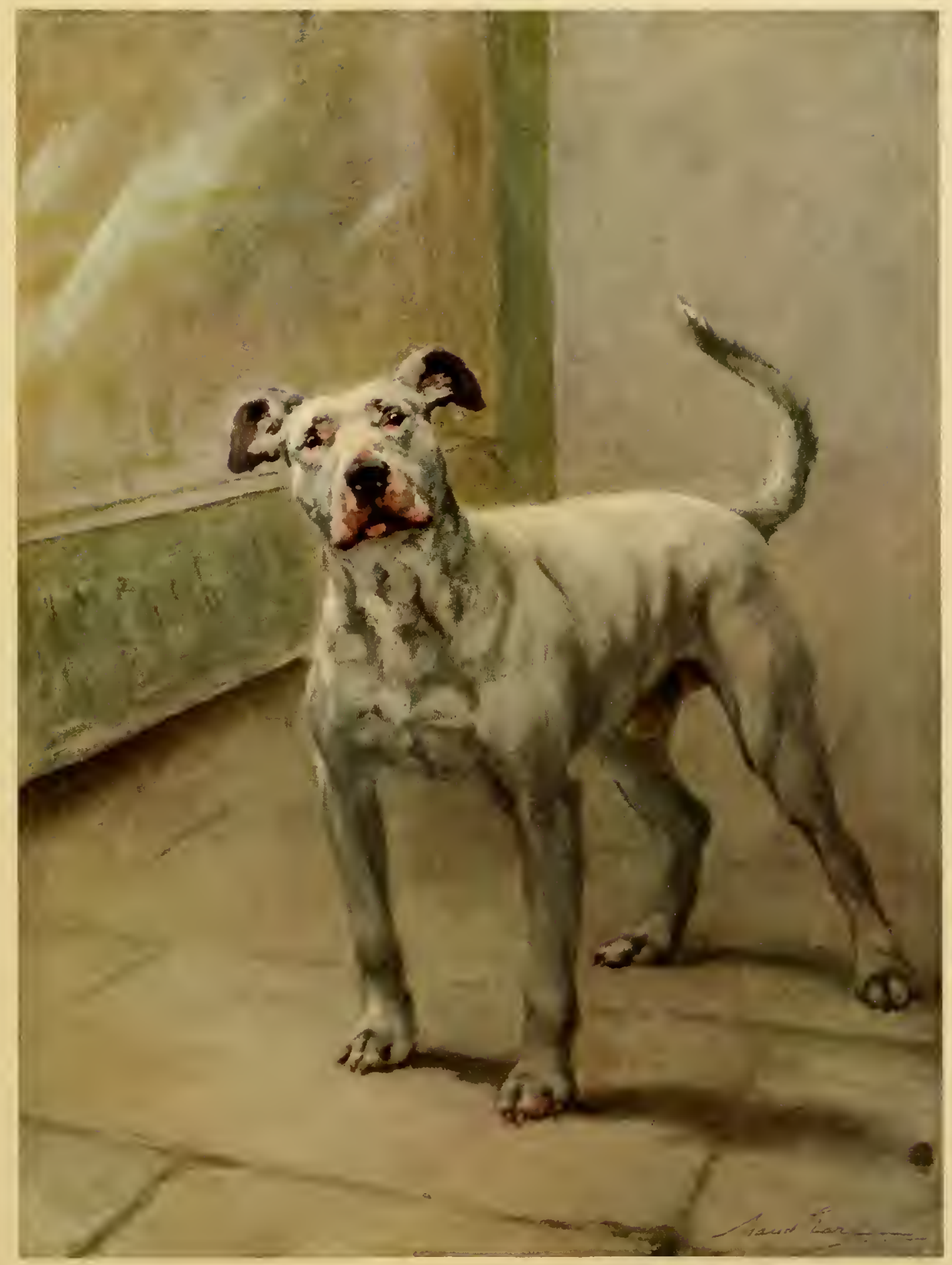


r 
"For ways that are dork, And for tricks that are rain, The heathen Chinee is peculiar."

Bret Harte.

$$
\begin{aligned}
& \text { CHOIV "Champion Papoose" } \\
& \text { Ow'net by" Mrs. Limel Fandel Phillips }
\end{aligned}
$$




\section{THE CHOW CHOW}

"Beasts which Buffon never knew."

W English are curiously eclectic in our tastes, canine as well as philosophical. Not content with what we have, we go on ransacking the world for something new, something strange, something that no one else has got, until in the process of time the variety we have acquired becomes so acclimatised that we almost think it our own. Among the strangers from the uttermost parts of the earth which have enriched the ranks of our domestic canide, the CHow CHow holds high position, but, though he is with us, he never seems to be a part and parcel of our lives. Watch his demeanour. See him going through life occupied with his own concerns; rather, preoccupied, I should say, for he has a singular indifference to his surroundings. Is his mind in his old home in the far East?

"For the temple bells are callin', an' it's there that I would be." Perhaps, pondering the deeper mysteries of this world, he has arrived at Thoreau's conclusion that: "Public opinion is a 
weak tyrant compared with our own private opinion. What a man thinks of himself, that it is which determines, or rather indicates his fate." The Chow gires one the impression of being a wise dog, who has inherited the impassive demeanour of his original Chinese masters. Mankind, as a whole, has no interest for him; he attaches himself to one person with great fidelity; to others, his demeanour, if not actually surly, is that of mere toleration. If you meet one with whom you have a bowing acquaintance, in the street, and speak to him, there is no responsire morement of the tightly-curled tail, no relaxation of the muscles of the grim face. You feel hopelessly snubbed, any orertures of friendship are summarily rejected. On reaching a new home, the Chow may be weeks before he is reconciled to his position, and you almost despair of the ill success of your efforts to establish cordial relations. Then comes the day on which he decides that you will do, and thence onward he is your liege man, offering you all the homage of which his nature is capable. In many respects he fulfils the nine conditions of Confucius's "superior man." In expression he is benign, in demeanour decorous, in duties respectful. I should not care to say, though, that in resentment he thinks of difficulties, for he will not take kindly to correction.

From these remarks it will be gathered, if I have made my meaning clear, that he is a dog who attaches himself devotedly to one person, while the rest of the world has no part in his existence. 
I know of no other dog with such strongly marked individuality, eren in his tongue he elects to he eccentric, for that is of a deep black, instead of the ordinary Hesh colour. There are other peculiarities about him which call for mention. For instance, if you are tired of him as a pet, certain parts of his body are regarded as delicacies fit to be served upon the table. The Chinese epicures, I believe, content themselves with his feet. As he lives mainly upon rice in his Oriental home, the idea of an edible Chow Chow is not quite so repulsive as if his subsistence were of a carnirorous kind.

Then the Chow has a more fully dereloped sense of locality than most dogs. He will return to his home with unerring instinct although he may have seen it but once before---even the intricacies of London streets present no difficulties to him. Some friends of mine once took their Chow to the sea, living in one house for a week and then moving into another. The first morning of their change of residence they lost the dog when out for a long walk, but he came back to the new place without the slightest hesitation. Nothing pleases a Chow more than the opportunity of wandering about as fancy pleases him. In his long and solitary rambles he will stroll round in apparently aimless manner, not so much as saying "good day" to another of his order who may happen to pass. Should, howerer, the stranger dog show a disposition towards belligerency, he may hase reason to regret his temerity, 
for the Chow's jaws are powerful, and his dense coat is almost as effectual a protection to his Alesh as a suit of mail. It is not usual for him to come off second best, and his nature bids him renew the conflict whenever occasion serves.

In appearance the Chow is distinctly faroured, lis short cobby body, straight forelegs, and powerful hindquarters making him look compact and strong. The small pointed ears, carried stiffy erect and forward over the eves, are a fitting completion to the head, which needs to be broad and Hat. The cxpression should be scowling rather than benevolent. Indiridual taste may have much play in the choice of colours, as we may choose from all black, red, yellow, blue or white. At present the red seems to be the most in demand, although efforts are being made to popularise the blue. This is a rery beautiful colour when we get it in purity and brilliancy, but so many blues have a rusty tinge which is by no means agreeable. The blacks, too, sometimes suffer under the same disability. Owners of blues and creams complain that it is of little use exhibiting them, however typical they may be, owing to the judicial preference for the reds. Well, I may be wrong, but I should always be disposed to put shape and type before colour, presuming of course, that the latter came within the standard. The head is one of the most characteristic features of the Chow, the blunt, broad muzzle having nothing of the Pomeranian or foxy style about it. 


$$
\checkmark
$$




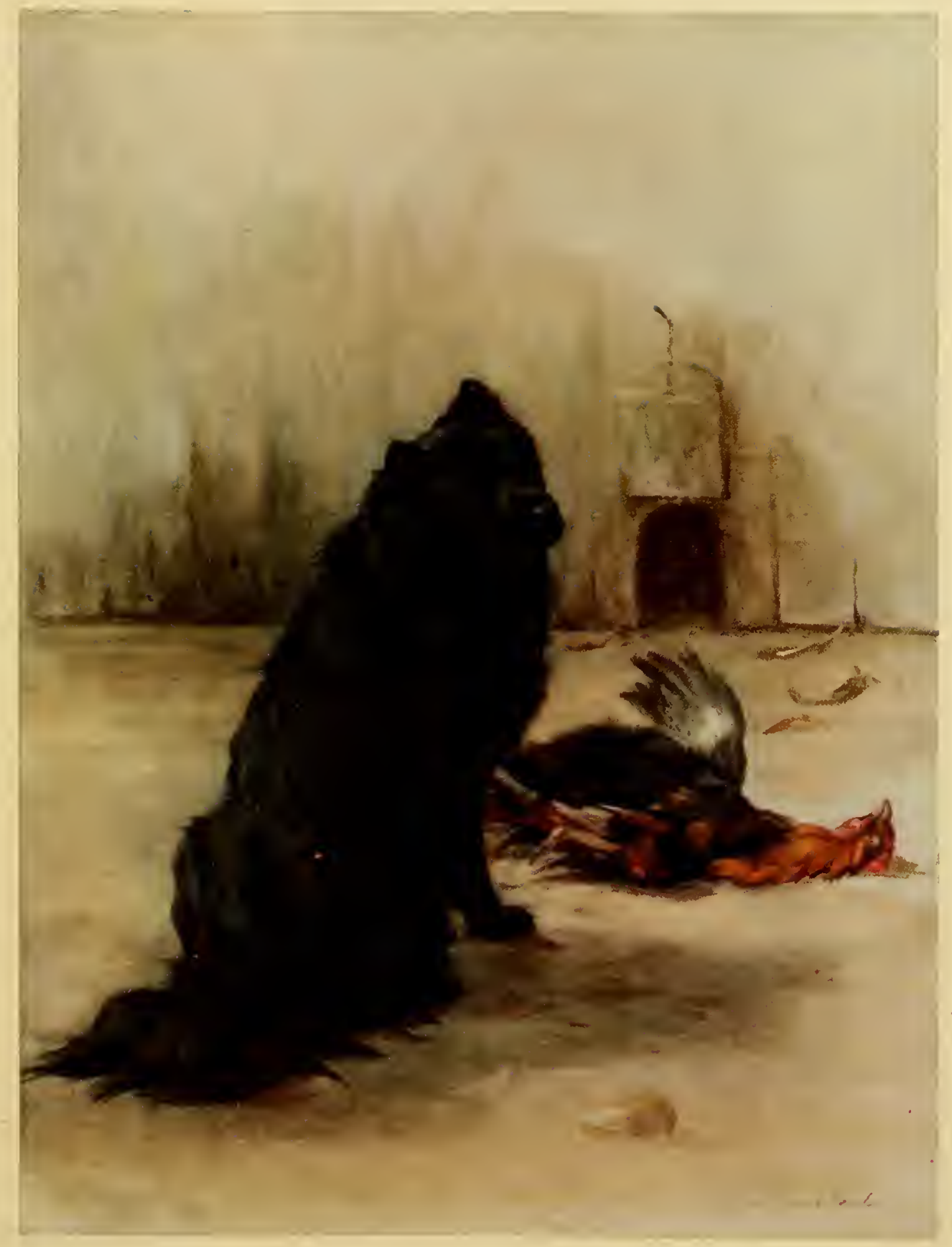



"For we are Ancients of the earth."

Tennison.

PEKINGESE

"Nan Tye of Newnham" \&o

"Ch. Mai-Mai of Newnham"

Ozened by Mrs. Irilliam Herbert 


\section{THE PEKINGESE \\ "There are three persons, mind you, to be' attended to; my lord, my lady, as the case may be (usually the latter), the pet danghiter, and the pet dog." \\ "Vivian Grey."}

UT there is meither East nor West, Border nor Breed nor 1 Birth" when great ladies of the Occident decree that dogs of the Orient are worthy of acquisition. Thus it comes about that one of the most popular toy dogs of the day is the Pekingese--the Palace dog of his own land, treasured and guarded by many generations of Emperors and Empresses. Even to-day in China the task of collecting individuals outside the Royal palaces is attended with the utmost difficulty, and great must be the amazement of any untravelled Chinaman who sets foot in this country for the first time on seeing so many about. Our own history of the breed begins with the advance of the French and English troops upon Pekin in 1860 . The occupation of the city being a formidable undertaking for such a small body, the allies made a movement on the Summer Palace of the Emperor at Yen Min Yuen, nearly four miles from Pekin. The victory was of a Pyrrhic 
nature, as the defenders fled. When the British soldiers entered the Palace much booty had already been removed, but several of the Emperor's favourite dogs remained behind, two of which passed into the possession of Lord John Hay. Two more became the property of an officer, who subsequently presented them to the then Duchess of Richmond, and General Dunn picked up another, which he had the pleasure of giving to Queen Victoria. So the story usually ends in most of the literature upon the subject, but, reading through some old volumes of "Country Life," dated I 899, I find that there were others, of which sight had been lost. Admiral Oliver Jones, then a Captain, who was present on the occasion, has stated that there were six, the mother and five puppies, one of which he had. A month or two later Mr. H. Townshend wrote to say that two officers of the 99th Foot also got a couple, from whom puppies were born in Canton. Mr. Townshend brought home one which lived for seventeen years, and was one of the most perfect animals in intelligence and habits that he had ever met.

The last remark probably explains the spell which these little creatures seem to cast over their owners. Superficially, one might think that the English toy spaniels should never be supplanted by the Chinese, and as far as mere beauty is concerned one would assign the palm to the lovely Japanese, but the Chinaman has come and conquered. He must be endowed with some intrinsic merits which are not apparent to the casual observer, one of which 
undoubtedly is the soundness of his constitution, a capacity for withstanding diseases to which others succumb only too readily. Whether this immunity will be retained or no is a debatable point. When the breed first started upon its career of popularity some twelve or fifteen years ago the numbers were strictly limited, and much inbreeding must have been necessary. While this may mean the perpetuation of a desired type it connotes also the possibility of an increased susceptibility to discase. The longevity attained by the earlier importations is sufficient proof of their stamina then. The letter I have quoted speaks of one reaching seventeen years, an age exceeded by a year by one of Lord John Hay's.

The charm of so many Pekingese that I have seen is that although toys in weight there is nothing toyish in their dispositions. They have all the boldness of bigger dogs, a fine capacity for devotion to master or mistress, engaging manners, tenacious memories, and indefatigable activity, all of which are virtues to justify our regard.

Externally they should have a massive front, tapering off behind the ribs to a distinct "waist," a conformation which is supposed to give them a leonine aspect. The legs should be short, heavy of bone in front and bowed outwards at the elbows. The head needs to be massive, with a broad flat skull, wide between the ears. The body must not be long. On the other hand, 
the coat should be profuse. Altogether you want a big dog in a small compass.

Bearing in mind the long ancestry of the Pekingese, the many centuries through which he has been the spoilt child of fortune in that inscrutable land whence he comes, it should not be a difficult matter to maintain the type in its correctitude, but critics are already complaining of the introduction of undesirable features, such as long legs, flat sides, and so on. I have on other occasions pointed out that the true toy at his best should not be merely a weed. Nearly anyone can get a light dog if he is bred from indifferent parents, and subjected to semi-starvation during the growing period. The real enthusiast, however, is not satisfied with such a miserable travesty, and people who buy Pekingese as pets should insist upon having those that have plenty of bone, and are sturdily put together. The expert is not likely to be misled by these aptly called " flatcatchers." It is the novice who is to blame by creating the demand for a tiny specimen, without regard for his make and shape. 



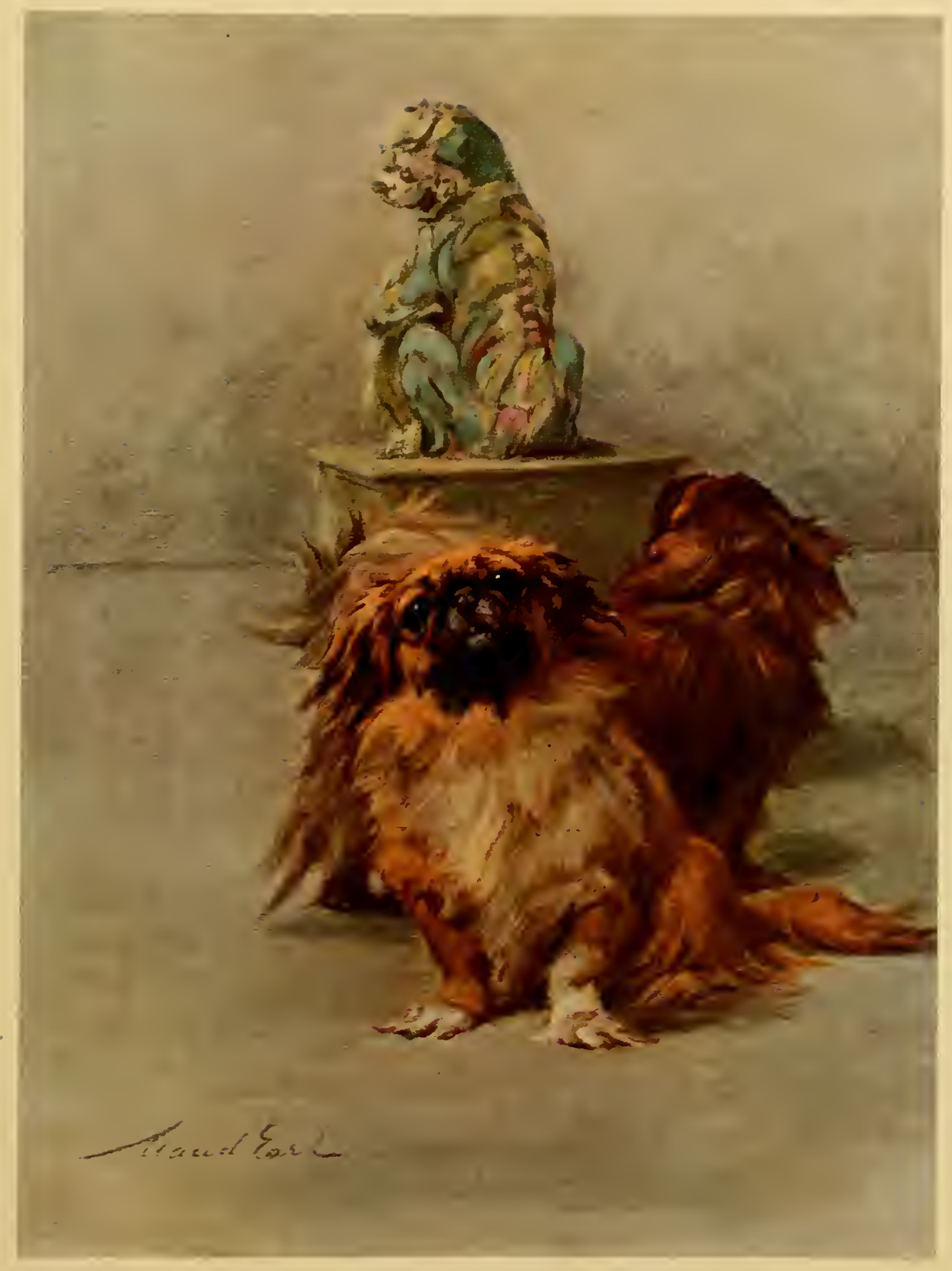



"O mistress mine, where are you roaming?"

Shakespeare-Tevelfih Nighl.

\author{
MINIATURE POMERANIAN \\ "Gatacre Betty" \\ Oaned by Mrs. Hall Walkir
}




\section{THE MINIATURE POMERANIAN \\ "In small proportions we just beauties see; And in short measures life may perfect be." \\ Ben Jonson.}

"TJ THAT do you lack, what do you buy, mistress? A fine hobby horse, to make your son a tilter? a drum, to make him a soldier? a fiddle, to make him a reveller? what is't you lack? little dogs for your daughters?" What is it you buy, mistress? Little dogs for your daughters? Not so, but little dogs for yourselves, and none do you favour more than the Pomeranian, miniature or otherwise---this dainty, elfin-like whimsicality, charming in form, beautiful in colouring, and graceful in manners. The vogue of the Pomeranian calls for no explanation, so self-evident are the reasons. Men as a class are drawn towards the sporting dogs, terriers, setters, pointers, hounds, spaniels, but no woman yet set eyes on one of these midgets without succumbing to its attractions. Rapid though the advances made by the Pekingese have been, the Pomeranian has not lost ground in any sense. It may be that he would have won still more supporters if it had not been for the 
advent of the Celcstial. That I will not dispute, but there are few defections from the ranks of the enthusiasts who have fashioned him into what he is. They remain true, despite the blandishments of others.

The Pomeranian owes his position to no adventitious circumstances; he has won his way into our hearts by sheer merit, until to-day he is to be found among all classes. Queen Alexandra's Marco is said to have ranked high among her many favourites, and he carried himself in a manner which showed a consciousness of his own vast importance. In one respect these dogs differ from most toys. A few years ago the slums of the East End provided Pug breeders with many a fortunate find; in Yorkshire and Lancashire Yorkshire terriers frequently serve as a source of income for the working men, who bring them up in their homes, converting the kitchen dresser into kennels; the Griffon Bruxellois, as has already been mentioned, was preserved from extinction by the labouring classes of Brussels when he had fallen into neglect in high circles. The Pomeranian, on the other hand, is usually a denizen of wealthy or middle class homes, although in certain cases working men and women are the owners of important kennels.

The Pomeranian is not alone an aristocrat of the show pen. Take a walk wherever Society may congregate, in the West End, on the front at Brighton in the winter months, at Harrogate or any 
other place frequented in its season by members of the great world, and there you will see him in force, escorting his beloved mistress with all the assurance in the world. So gay and irresponsible is his action that you might well describe him as the butterfly of the canine race. No doubt the demand from the general public, regarded from the point of view of the expert, is not wholly without its drawbacks, for the patent reason that, in the efforts to cope with this demand breeders are not always particular about keeping up the level. Having this fact in mind it is encouraging to think there are not more bad ones about.

If Darwin had been living the story of the Pomeranian would have furnished him with some admirable illustrations of the variations that man is capable of producing in the canide within the space of a comparatively few years. Half a century ago the dogs that were imported into this country were mainly white, weighing twenty pounds or more. If we enquired into their origin the conclusion would be forced upon us that they were of sub-Arctic extraction, the resemblance to the dogs of the colder regions rendering any other conclusion impossible. We note the similarity in coat, the foxy-shaped head, the tightly-curled tail, and the erect ears.

One has not to be very old to recall the gradual reduction in size, going side by side with the introduction of new and beautiful colours, which are mostly of great brilliance and purity. There 
are whites, blacks, browns and sables in several shades, orange, blues, beavers, chocolates, black and whites, racoons, tricolours and others---a range exemplified by no other variety. One has almost to be an artist to follow the subtle gradations, which, however, can be appreciated by the most commonplace Philistine. When we contemplate the wonderful creations we are amazed at the cleverness of the ladies engaged in the pursuit. Nature plays strange pranks in relation to her colour schemes, and the most skilful breeder is she who has an encyclopædic knowledge of the mingling of blood necessary to bring about a given result. The problem is further complicated by the influence of the law of heredity, and some of the most exquisite shades have come by chance in the first instance.

The desire for small specimens, many of which may weigh no more than two and a half pounds, has led to a sub-division of the variety into Pomeranians and Pomeranians miniature. It is one of the latter that Miss Earl has so well depicted. 



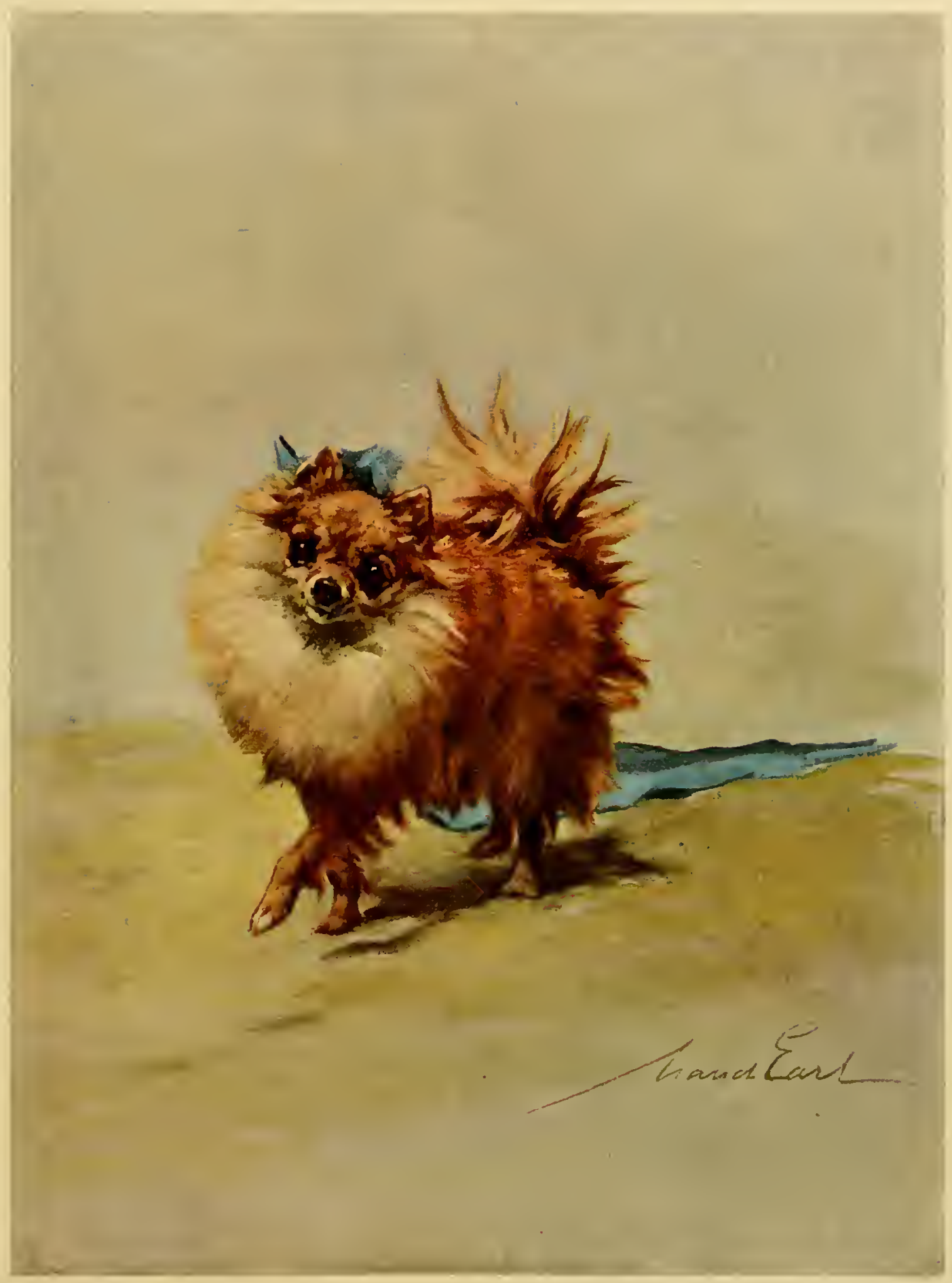



" $O$, how full of briers is this working-day world!"

Shakespeare-is Tou Like It.

\section{ENGLISH SPRINGER "Tissington Flush" \\ Oaned by Sir Hugn Fitwherbert, Burt.}




\section{THE ENGLISH SPRINGER \\ "The chiff requisite in all kinds of spamiels is, that they be good finders, and have noses so trite' that they will never azerrun a scent. . . . . They should be high-minettled, as regardless of the severest aceuther as of the most punishing cover, and ever ready to spring into the closest thicket the moment a pointed finger gives the command."}

General Hutchinson.

7 HE transition from the toy varieties to a spaniel is somewhat violent. The one is intended to please the eye, to gratify the æasthetic sense, and charm by his manners in the house; the other is designed primarily, by serving the sportsman in the field, to accomplish useful duties, but at the same time his docility of disposition, sagacity of expression and beauty of coat make him also a welcome companion when the day's labours are ended. In estimating the worth of a gundog I should lay much stress upon his fitness for associating with mankind, for there is no doubt that if we win the confidence and friendship of our four-footed servitors the pleasure in their possession is much increased, and we have 
them under far better command when at work. Of all the foolish things written the hackneyed couplet so much quoted has precedence:

"A woman, a spaniel, and a walnut tree,
The more you beat them, the better they be."

The ladies are quite capable of looking after themselves, and need no champion. I daresay a walnut tree may be all the better for a good "splashing," as we used to say in the Midlands, but I am certain the less a whip is used on a dog of any sort the more likely are we to be successful in our efforts to exact prompt and ready obedience to our commands. The man who uses physical correction too freely is in want of a practical application of the monition contained in the Book of Proverbs: "A rod for the back of fools."

Of the many handsome sub-varieties of spaniels with which we are familiar to-day the English Springer, perhaps, enjoys the least popularity, although his merits as a worker entitle him to a high place in our regard. As a show dog he has never assumed much prominence, but at field trials and on private shootings he is constantly demonstrating his utility. No other spaniel has been bred less for "points" or more consistently for work. Less excitable than the volatile Cocker, his longer legs and sturdier frame adapt him to purposes which the smaller is unable to perform. On the other hand, unless well broken, he, by ranging too far atield, 
may put up the game out of gunshot. It therefore follows that in his early days he must be made absolutely steady. Whether he becomes so or not is not so much attributable to the inherent wickedness of the dog as to the lack of patience in his breaker. One is almost inclined to say that the good breaker is born not made. At any rate, supposing you have the leisure, this is a task better undertaken by yourself than entrusted to a gamekeeper, who may have neither the time nor disposition to act as a wise schoolmaster.

A Springer is large enough to retrieve both fur and feather, but whether or no he should be encouraged to do this depends upon circumstances. General Hutchinson says: "When a regular retriever can be constantly employed with spaniels, of course it will be unnecessary to make any of them fetch game (certainly never to lift anything which falls out of bounds), though all the team should be taught to 'seek dead.' This is the plan pursued by the Duke of Newcastle's keepers, and obriously it is the soundest and easiest practice, for it must be always more or less difficult to make a spaniel kcep within his usual hunting limits, who is occasionally encouraged to pursue wounded game, at his best pace, to a considerable distance."

The word Springer is applied to all medium-legged spaniels, as apart from the short-legged ones, that are neither Clumbers nor 
Sussex. It is of good old English derivation, denoting the object for which the dog was employed---to spring birds to the net or gun. The form of the dog has not undergone any marked change since a Dictionary of Sport, published shortly before Queen Victoria came to the throne, spoke of him as differing but little from the Setter, except in size, being nearly two-fifths less in height and strength. He is of symmetrical formation, varying a good deal in size from thirty pounds to sixty pounds, with unbounded energy. He may be a self-coloured liver, black, or yellow, or pied or mottled with white, tan, or both. Miss Earl's picture brings out beautifully the correct shape of his body, and the handsome intelligent-looking head. Older pictures suggest that a hundred years ago or less the skull was broader between the ears, and the head shorter, but the refining process has not been carried far enough to jeopardise the brain power. In many breeds I have noticed that a broad skull indicates self-will and stubbornness, and therefore it seems to me that the slight change is all for the better.

The other variety of Springer indigenous to Wales is quite distinct from our own. He is smaller in size, and in colour he is red or orange and white, preference being given to the former. 


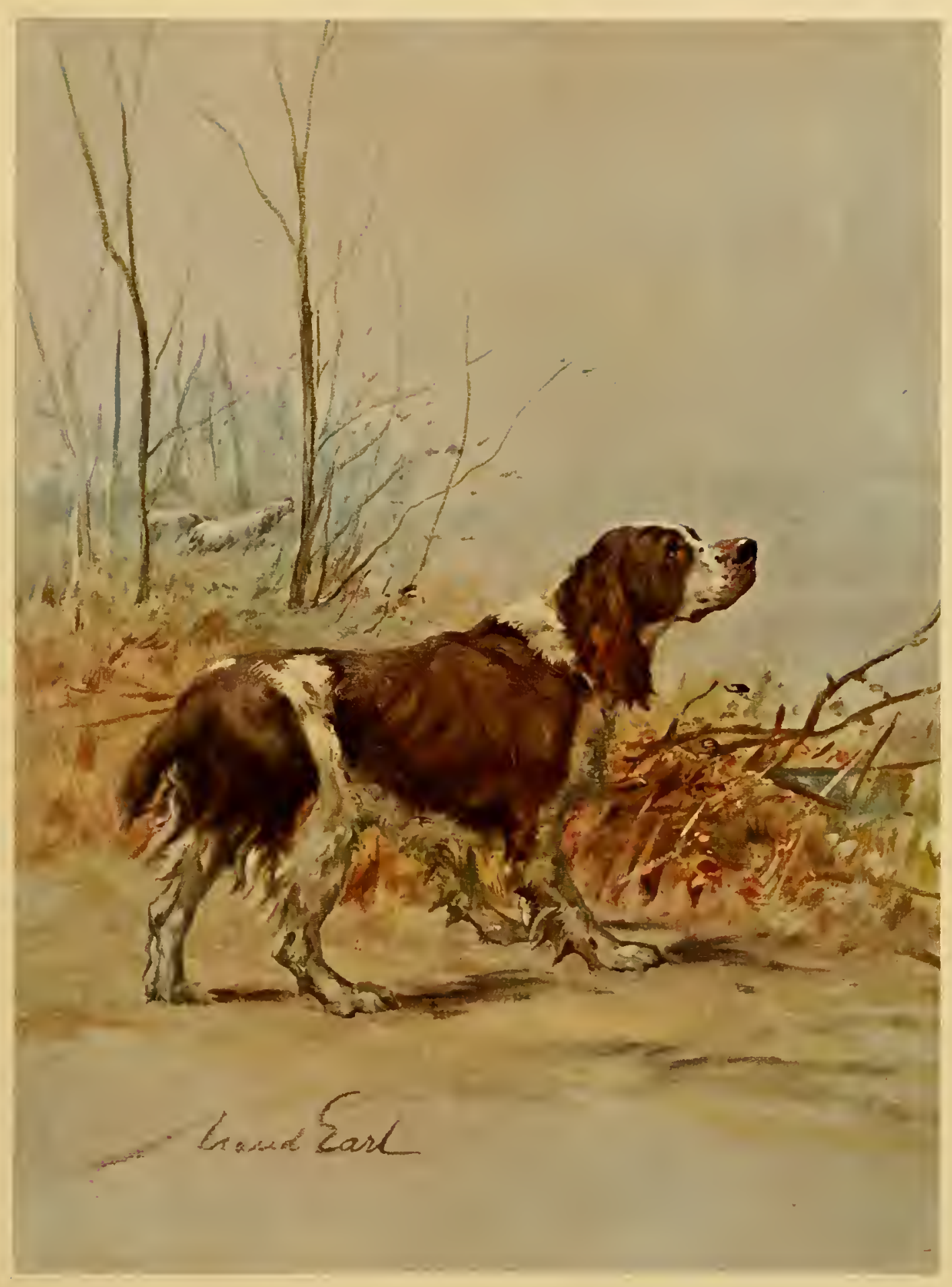



"Shall I tell you what it is, gentlemen of Boston?"

MaLt Whitma.:

BOSTON TERRIER

"Feffries Funior"

Orinded hy Miss Cilundiui Lasill 


\section{THE BOSTON TERRIER \\ "I ann ann American-and whenerer I look up and see the stars and stripes soerhead, that is home to me."}

Oliver Wexdell Holmes.

HE United States is a great country, full of many beautiful
and wonderful things, but strangely enough it has grown few dogs of its own, the native varieties being singularly limited in number. Although the Boston Terrier is also an exotic, being composed of materials imported in the first instance from Great Britain, we would not be so churlisin as to rob our American cousins of one of their most cherished possessions. He is named after the "Hub of the Universe," and that must suffice. The Americans annex all that is best of our own brceds. It was they who gave Eor,300 for a St. Bernard, nearly as much for some collies, and over a thousand for several bulldogs, but we have never reciprocated by introducing the gentleman from Boston. Perhaps, in the interests of good feeling between the two nations, it is as well that we have not done so, for the chances are that if we had we should have altered his style, changed the standard of points, and made 
him something altogether different. That is a little way we have, a way that occasionally causes a proper resentment in other lands.

I will not venture upon a speculation as to the reason why we have decreed the French Bulldog to be worthy of our esteem, while the Boston Terrier has been neglected. The two have many superficial points of resemblance; indeed, it is almost necessary for one to be an expert to detect the difference. Both are built much upon the same lines, and the heads are not greatly unlike, except that the ears of the American dog are cropped instead of being allowed to retain their natural shape. This is not surprising when we consider that the Boston Terrier was formed from probably the same foundation stock---the fighting dog from Birmingham and the Midlands, fined down with an admixture of Terrier blood. The result is an active, game, "trappy" little fellow, fit for my lady's carriage or as a friend of the working man. My introduction to the Boston Terrier took place at the Villa d'Este, upon the shores of the Lake of Como. Passing an idle hour or two in that beautiful spot one afternoon my attention was suddenly arrested by the appearance of a dog of strange appearance. A second look told me his description, and his owner, a charming American, was quite pleased to find an Englishman who knew a little about her favourites. In the summer of I 9 I I, I had a further opportunity of renewing my acquaintance with the breed, a lady exhibiting some specimens at the Ladies' Kennel Association show in the 
Royal Botanical Gardens. With these exceptions, my knowledge of the Boston Terrier is confined to reading and hearsay, but from what I can learn I imagine that there is much to commend him. Were it not so, it is hardly probable that such a dog-loving race as the Americans would make a furore about him. Over two hundred and fifty have been benched at one show, and a good one is worth anything from $\delta$ ioo to $f_{4} 00$.

The Boston Terrier has blossomed into a dandy of high breeding, with his even white markings usually on a clear brindle body. Was that the intention of the men who produced him in the first instance? My impression is that the desire was to manufacture a gladiator fit for the pit; and a cross between a bulldog and a terrier would be about as useful as anything for this horrible purpose. Fate, however, had in store for him a kindlier destiny than mauling his fellows and being mauled in turn. 




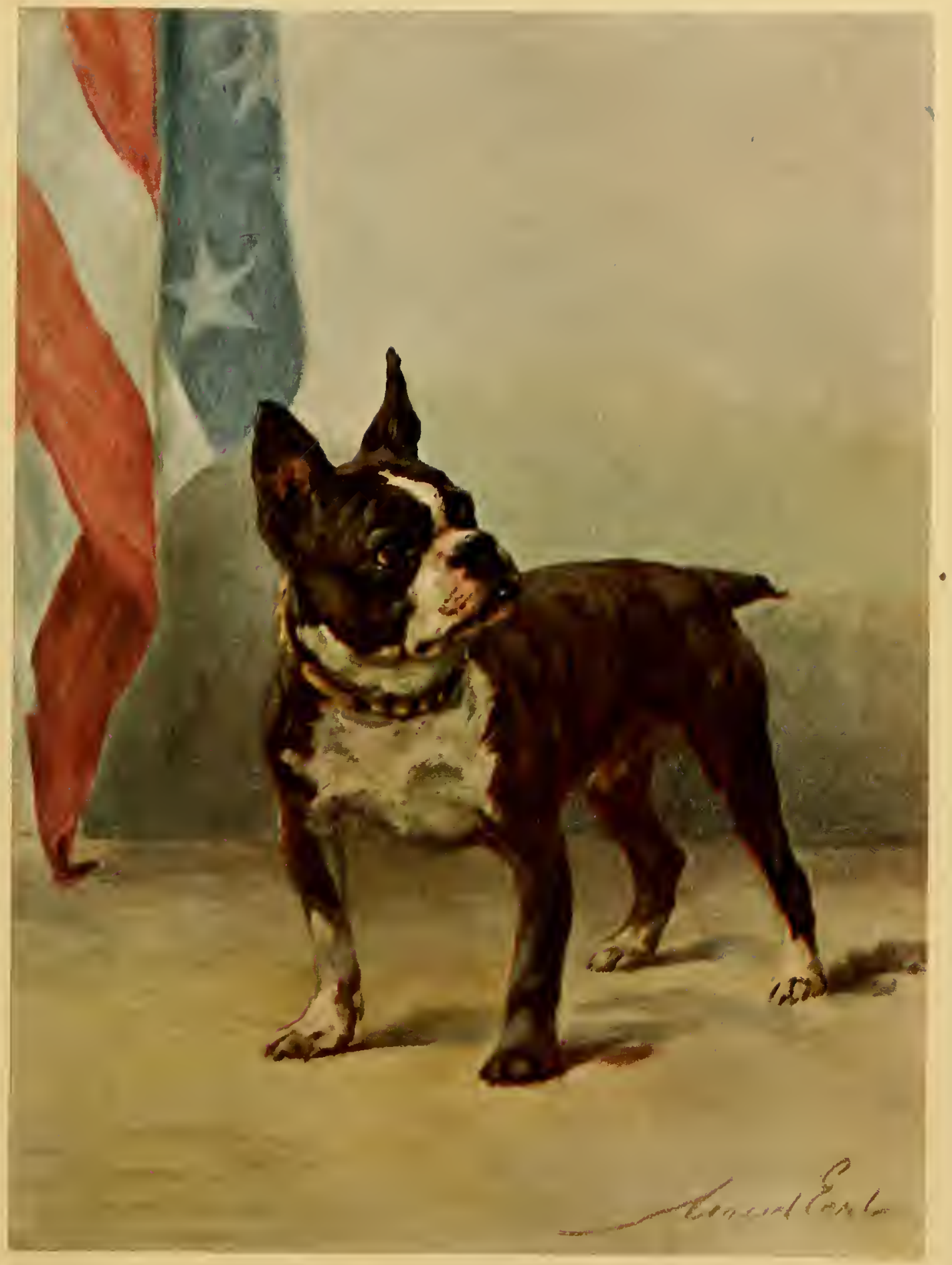



"And some loquacious iessels were; and some

Listen'd perhaps, but never talk'd at all."

Rubaivit of Oinar Khavian.

GRIFFONS BRUXELLOIS

"Park Place Presto"

"Park Place Pinkie"

"Champion Park Place Partisan"

"Esporance"

Ow'lled by" Miss Hall 
THE GRIFFON BRUXELLOIS

I'm a gay tra, la, la,
With my fal, lal, la, la,
And my bright-
And my light-
Tra, la, la.
BRET HaRTE.

TF you meet a dashing man about town, with a ferocious beard 1 and moustache, a very much abbreviated nose and an ape-like face, you may be sure that he is a Griffon Bruxellois, or, as he is more familiarly termed, a Brussels Griffon. If his inches are few, and his weight is not more than from five to ten pounds, he has all the militant carriage and gay debonnair of an accomplished worldling. Cheek, impudence, pluck, confidence are all his, mixed with, perhaps, a good deal of braggadocia. A modern High School Miss might even say that he had swank, a word which once excited the curiosity of Mr. Justice Darling when trying a case arising out of an election. With all that innocence permitted to the judicial bench, he enquired if it were a local term peculiar to Lowestoft. I regret to say Counsel seemed to regard it as a vulgar word, 
although I would point out with all diffidence that it is as old as Burns---

Here farmers gash, in ridin graith

Gaed hoddin by their cotters;

There, swowkies, young, in braw braid claith

Are springin o'er the gutters.

Of cheerful yesterdays and confident to-morrows, it may be said of him, and the consequence is that if you once have a Griffon you will always want to have one. Although among the toys he is not of them, being a thorough sportsman all the way through. $\mathrm{He}$ will do everything that is possible in this direction permitted of his size. I am sure that he has often wished that he were bigger, so that he could take his part with the terriers. The spirit to tackle fox or badger is his if the physique has been denied him.

The name tells you whence he comes, and about seventeen years have passed since he was brought over into this country. Before assenting to the generally accepted version of his origin it would be well to enquire more closely into the matter. It is said that he has sprung from the Yorkshire and Irish Terriers mixed with the English Toy Spaniels, and that the years to his credit as a distinct variety are not many. Is this correct? Mr. Howard Spicer, whose interest in the breed has induced him to make rescarches on the Continent, thinks otherwise. The picture galleries will help us in our quest. In the painting by Jan Van Eyck, dated 
$\mathrm{I}+3+$, of Arnolfini and his wife we are fortunate enough to have a very clear and lifelike portrait of their pet dog in the foreground. The painter evidently went to some pains orer the animal, which in many respects is singularly like the present-day Griffon, the most noticeable divergence being the longer face of Arnolfini's pet. He has not the snub nose of our own dogs, but the photograph of one of the older champions shows that this feature is of recent derelopment.

To cite a further instance, between the years i 554 and r640, says Mr. Spicer, Jacopo du Empoli is credited with the production of a picture of a dwarf, in the employ of Henry III. of France, which portravs amongst a collection of this monarch's pets, two unmistakeable griffons. After this evidence it will be unwise to jump too readily to the conclusion that the Brussels Griffon is a modern breed fashioned from British materials. We know perfectly well that toy dogs have been in vogue through all ages, and these not only of the spaniel kind. No great exercise of the imagination is needed to see among them the Griffons Bruxellois or their progenitors.

Miss Earl in her picture has well caught the spirit of diablerie manifest in these mannikins. Is it matter for surprise that lovers of the eccentric should profess a derotion for them, that when, for some reason or other, they fell out of farour with the great ladies 
of the courts and salons, small shopkeepers and working men in Belgium should take them up and pass them on to England, and that our own countrymen succumbed to their quaint looks and ways? We have taken the craze so badly here that better examples can be seen at a leading show in England than can be found in the city after which they are named. The standard says that a griffon should be " intelligent, sprightly, of compact and cobby appearance, attracting one's attention by the quasi-human expression of its face." $\mathrm{He}$ is all that, and a good deal more beside. If you want one with the correct points faroured by exhibitors, see that his head is rounded and furnished with irregular hairs; that the upper lip has a moustache, while the chin is prominent or undershot, with a beard beneath. Let the nose be as short as possible, with a pronounced stop beneath the eyes. Note that the body is short, and that the docked tail has an erect carriage. Insist, too, upon the coat being harsh to the touch, red as that of the Irish terrier. The legs should be straight, and the feet rounded and knuckled up in the manner of a cat's. 



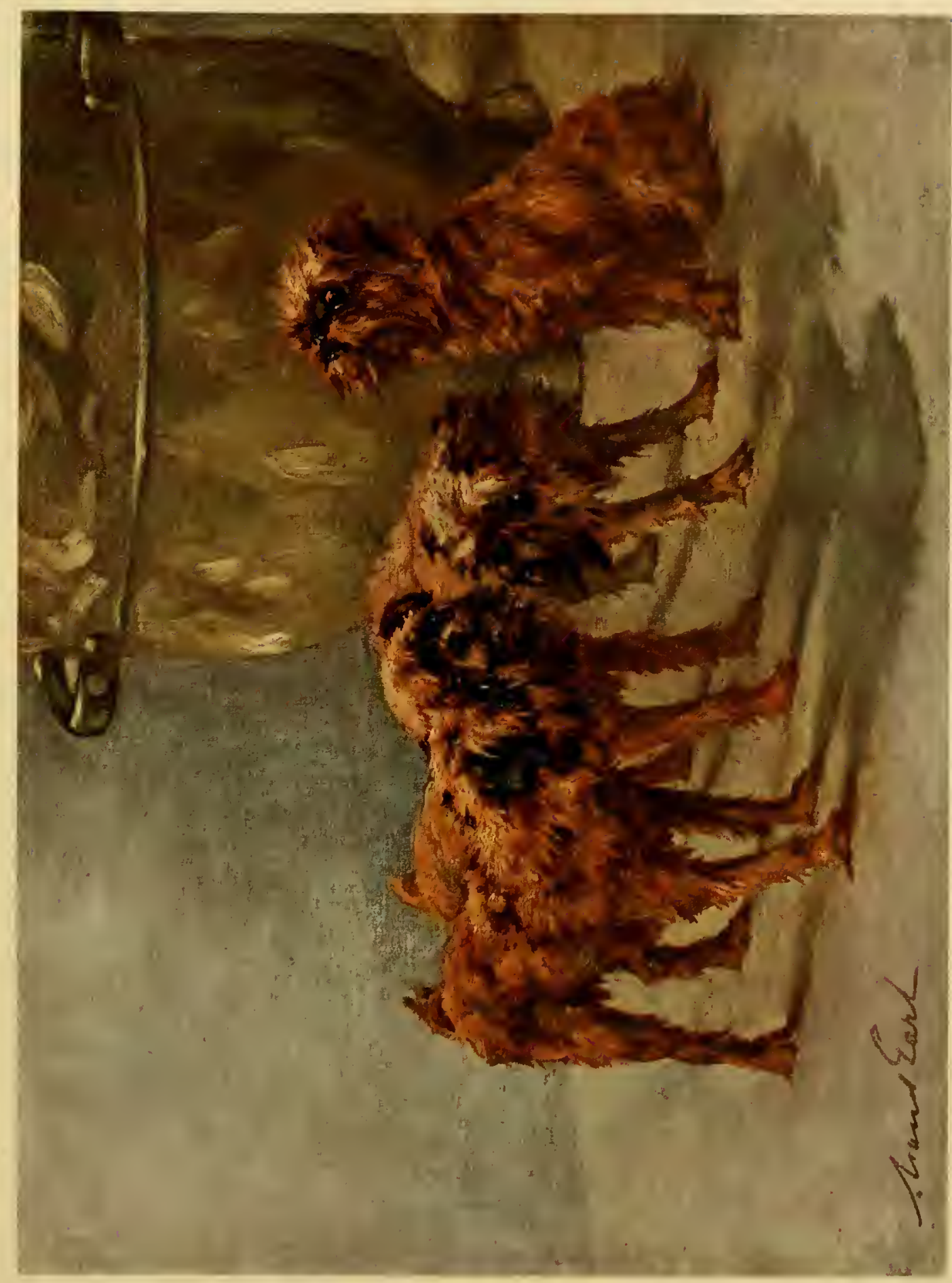



"But who is this? What thing of sea or land? Female of sex it seims, That is bedecked ornate and gay."

Milton-Samson Agonistes. 
THE MINIATURE POODLE

"My zoildest wishes he fulfils
Writhout a protest on his part;
My faintest show of friendship thrills
His faithful heart."
ELLEN THORNYCROFT Fowler.

T $N$ those days of Platonism and "sensibility," which formed 1 such a curious phase of the feminism of the Sixteenth century, no woman was happy without a pet dog, probably a poodle. Their love of animals was particular rather than general. As M. de Maulde says in "The Women of the Renaissance," "Ladies only valued the boudoir pet, the little, affectionate, obedient animal, their very own, which meekly took their kisses and upon which they lavished without misgiving a portion of their tenderness: a bird, for instance, or a pug. I say a pug, for there was seldom more than one. What was the good of a troop of shaggy animals, however graceful, like those which fill the canvases of Veronese? A lady much preferred her one little lap dog, which she carried on her arm against her heart, took to bed with her, and had painted in her own portrait." Probably the author is inexact 
in referring to these pets as "pugs," their resemblance to a tiny poodle being more marked. The chances are that the word "pug" is used in the sense of a pet.

One would not care to say that four centuries later many ladies are not wholly free from a charge of extravagance in their relations with toy dogs, although this is a reproach that cannot be directed against the owners of Poodles, who prefer to treat these intelligent creatures with due regard to their dignity. If in size the miniature Poodle approaches the toys, he still retains the sagacity and sense of his larger brother, who is a sportsman, in spite of the fantastic, not to say grotesque, guise under which he is compelled to masquerade. The curious manner in which Poodles are clipped is to a large extent responsible for the estimate in which they are held by the general public, who are blind to their virtues. In reality, it would be difficult to find a more faithful or a wiser companion, or a safer guard than a Poodle. Examine his head and and eye carefully, putting on one side the hair, and you will agree that the expression is indicative of wisdom and friendship.

Sixty years ago or more Youatt wrote what remains true unto this day: "These dogs have far more courage than the water spaniel, all the sagacity of the Newfoundland, more general talent, if the expression may be used, and more individual attachment than either of them, and without the fawning of the one, or the submissiveness 
of the other. The Poodle seems conscious of his worth, and there is often a quiet dignity accompanying his demonstrations of friendship." The frequency with which Poodles appear in troupes of performing animals is convincing testimony to their teachableness, an assertion which will be confirmed by anyone who has been on terms of intimacy with one. A Poodle may be taught to do nearly anything, his perspicacity being almost uncanny, yet we cannot say of him that he is widely popular. It may be that the function of clipping has its terrors, but, when this operation has once been properly performed, I doubt if his toilet is as troublesome as that of most long coated dogs. An exception must, however, be made in the case of the corded variety, the long ropes of hair dragging the ground and demanding skilled treatment. Such a coat has its obvious disadvantages. It is unhygienic because of the dirt which must inevitably accumulate, and from the fact that the cords at the end are composed of dead hair, which in the natural course of events should be shed. The heavy weight, too, of the cords naturally impedes the action, which should be graceful and full of liberty. The coat of the curly Poodle, which more often than not is now merely fluffed out, presents no obstacles. So far as the shaving is concerned, an inspection of an actual dog or photograph will reveal that it is carried out on a more or less well ordered system. Feet and legs are bare, except for bracelets which are left at the hocks and above the pasterns. A small tuft of hair remains at the end of the stern, the rest being denuded; the face is also cleared with 
the exception of a moustache on the upper lip; and about a third of the body is also stripped, two pompoms, however, being allowed on each side of the back.

Until some fourteen years ago, the commonly accepted colours were black or white, but when a red came on the scene as the result of a union of two blacks, the colour question at once assumed importance, and now we may have, in addition to the shades mentioned, blue, mouse grey, silver grey, cream or apricot, tan, smoke, chocolate, brown, pale fawn, etc. During the same period the miniature Poodle has received a great impetus. That is, officially, a dog measuring not more than fifteen inches at the shoulder, although as a matter of fact the aspirations of breeders is to get below this maximum. Strange to say, the large dog of recent years has been getting bigger, until we may have one weighing as much as sixty pounds, measuring at least six and twenty inches. The weight of of a miniature may come down to about fifteen pounds, which is sufficient to prevent him being weedy. It is to be hoped that no serious attempts will be made to reduce this to any material extent. 



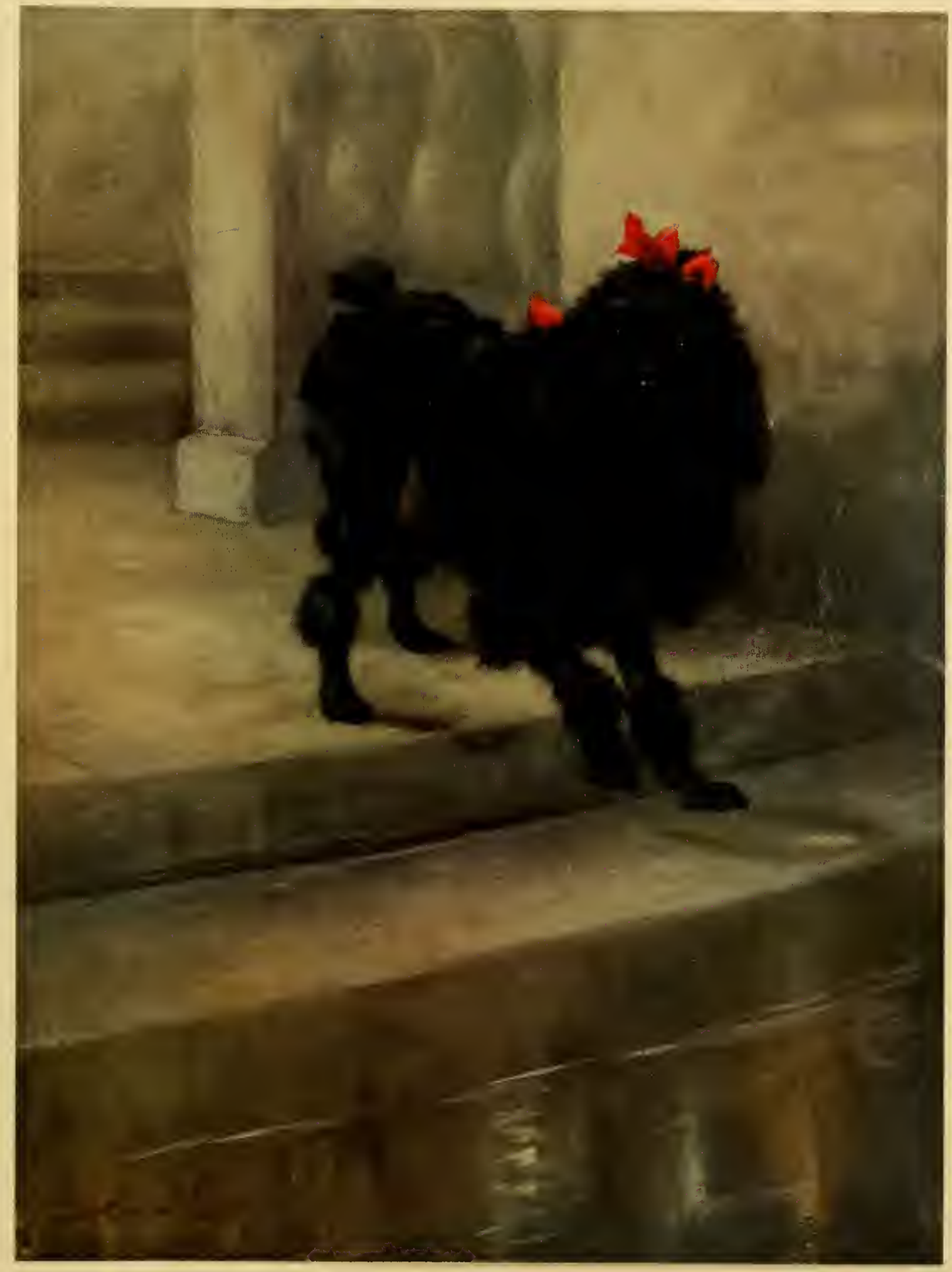



"Books cammot always please, however good, Minds are not always craving for their Food."

George Crabbe.

PEKINGESE PUPPY "Lu Chu of Newnham" Owned by Mrs. William Herbert 


\section{A PEKINGESE PUPPY}

"The word"friend' does not exactly depict his affectionate worship. He loves us and reveres us as thouglh we had drawn him out of nothing. He is, before all, our creature full of gratitude and more devoted than the apple of our eye. He is our intimate and impassioned slave, whom nothing discourages, whom nothing repels, whose ardent trust and love nothing can impair."

Maeterlinck.

ToUnG life abounds with a charm that can never be repeated 1 as days and months broaden into years. Even the calf, gambolling and frisking in the field, stupid and clumsy though it may be, is not wholly devoid of the magic of immaturity, and when we come to the puppy, the kitten, the cub of lion or tiger, we see grace and beauty in every movement, and a winsomeness that captures the fancy.

To experience the fullest pleasure in the ownership of a dog 
it is necessary that he should come into our possession when young, before his intelligence is formed, and innumerable other impressions crowd his brain to the exclusion of those we wish to impart. To watch the intelligence unfolding, to see the body developing, and the character chrystallising into the shape we desire it to assume, is a never ending source of joy. Day by day too, the little creature comes to depend more and more upon us, to recognise us as the chief god among the many strange beings that people this earth. When he is hungry we feed him. Is he thirsty? We give him drink. All the thousand and one little services that we render to him in the course of a week make him more and more irrevocably our debtor, and when the time comes for the state of pupilage to be shed we shall have a mature dog our devoted and obedient servant, ready to die for us if need be. In no other wise can we have quite the same understanding between master and dependent.

If you have not read Maeterlinck's essay on the death of a little dog you should do so at once. How well does he express the intimacy between a puppy and his owner. "I saw my little Pelléas sitting at the foot of my writing table, his tail carefully folded under his paws, his head a little on one side the better to question me, at once attentive and tranquil, as a saint should be in the presence of God. He was happy with the happiness which we, perhaps, shall never know, since it sprang from the smile and the 
approval of a life incomparably higher than his own. He was there, studying, drinking in all my looks, and he replied to them gravely, as from equal to equal, to inform me, no doubt, that, at least through the eyes, the almost immaterial organ that transformed into affectionate intelligence the light which we enjoyed, he knew that he was saying to me all that love should say."

There are, of course, drawbacks if we are lacking in patience and firmness. A puppy may sometimes be so trying that we think the very spirit of Flibbertigibbet has infused his nature, impelling him to mischief. If you happen on one like this, take him aside confidentially, reason with him, and point out to him that, however much gratification he may get at present from his reprehensible conduct, in reality

the unkind and the unruly,

And the sort who eat unduly,

They must never hope for glory-

Theirs is quite a different story.

Almost before you are aware of it his nature will have changed, he will have become a reformed character. No longer will he tear up your favourite books, as the reprobate in Miss Earl's picture is doing; the choicest plants in the garden will for ever after enjoy immunity; the children's toys will remain untouched; and on dirty days he will always wipe his feet on the mat before entering the house. Should he continue obdurate after your kindly counsels it 
may be obligatory to swish him, but let the punishment be given with gentle hand, even as the birch is administered by the sorrowing "Head" to the recalcitrant scholar. Remember though that youth has much to learn, experience is incomplete. Therefore, be tolerant, but let not your toleration be mixed with indulgence, unless you wish to rear up a tyrant, who will dominate the household and render your life a misery. Beyond certain well defined limitations the dog should not be allowed to step. As a sympathetic person you must treat him with kindliness, but never for a moment allow him to forget that respect which is due to you as a superior being. What is your opinion of the Prime Minister who fails to lead, of the General who consults a private? Each is unfitted for the position to which he has been called. So, too, is the man who abdicates his headship in favour of Fido. He has no right to own a dog. Puppies, like children, are all the better when subjected to reasonable discipline, and in using the word discipline I do not mean an excessive application of the rod or incessant nagging.

What is the fate of the merry mite so cleverly portrayed by Miss Earl? Youth passes, middle age comes, let him play and eat and sleep while the zest is on him, so that on the advent of maturity with all its troubles he may seek consolation in the memories of a happy puppyhood. 



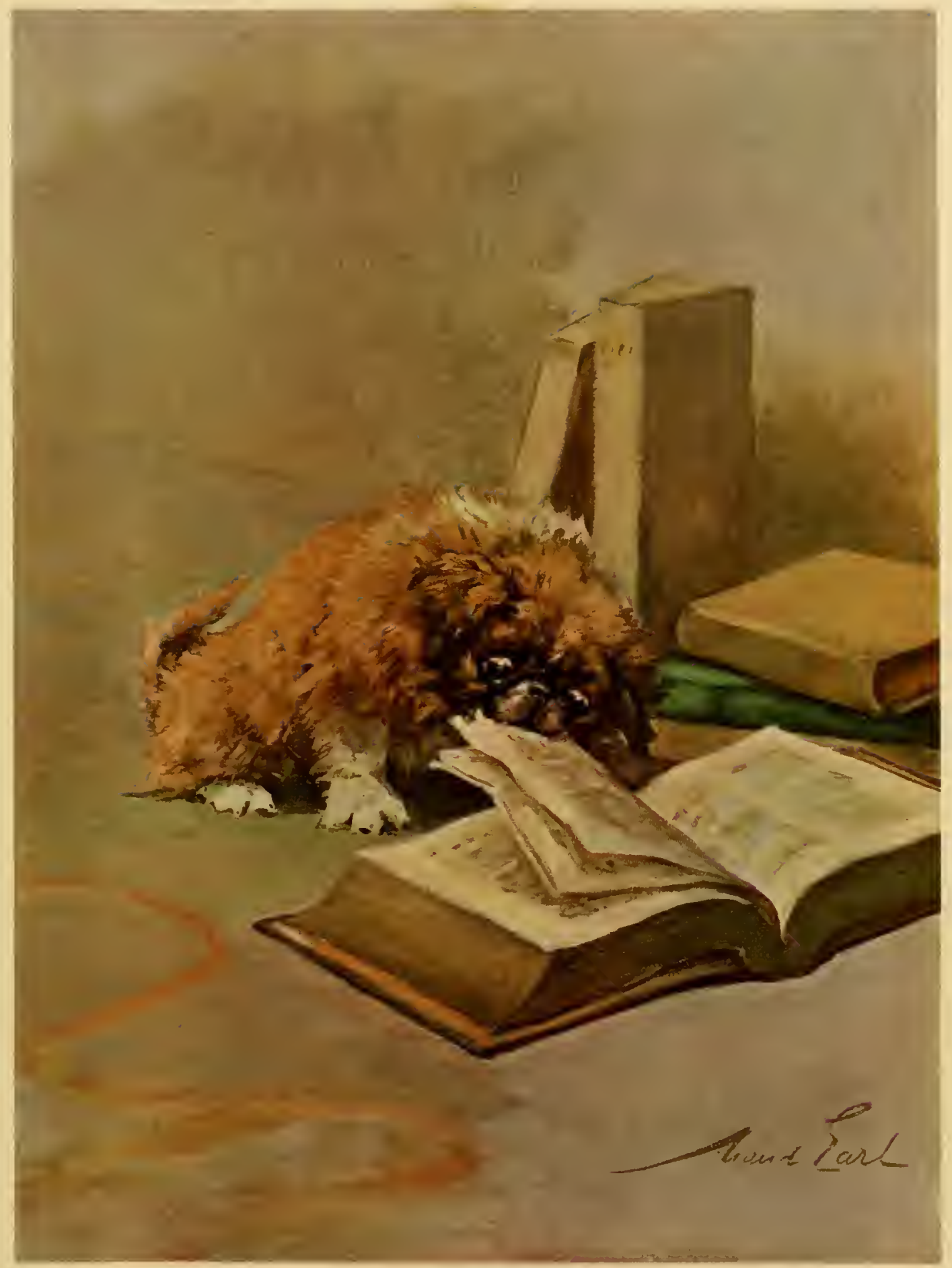






